\title{
Mosul Dam: Is it the Most Dangerous Dam in the World?
}

\author{
Nadhir Al-Ansari 1 - Nasrat Adamo • Sven Knutsson • Jan Laue • \\ Varoujan Sissakian
}

Received: 9 June 2017/Accepted: 11 May 2020/Published online: 25 May 2020

(C) The Author(s) 2020

\begin{abstract}
Mosul Dam is an earth fill dam, with a storage capacity of $11.11 \mathrm{~km}^{3}$ constructed on highly karstified gypsum beds alternating with marl and limestone. After impounding in 1986, seepage locations were recognized. The dam situation now indicates that it is in a state of extreme relative risk. If it fails, then 6 million people will be affected and $7202 \mathrm{~km}^{2}$ area will be flooded. Grouting operations will elongate the life of the dam but will not solve the problem. Building a protection dam downstream will be the best measures to secure the safety of the downstream area and its' population.
\end{abstract}

Keywords Mosul Dam · Tigris river · Iraq

N. Al-Ansari $(\bowtie) \cdot$ N. Adamo · S. Knutsson · J. Laue Lulea University of Technology, 97187 Luleå, Sweden e-mail: nadhir.alansari@ltu.se

N. Adamo

e-mail: nasrat.adamo@yahoo.com

S. Knutsson

e-mail: sven.knutsson@ltu.se

J. Laue

e-mail: jan.laue@1tu.se

V. Sissakian

University of Kurdistan, Hewler, KRG, Iraq

e-mail: f.khajeek@ukh.edu.krd

\section{Introduction}

Mosul Dam is located on the Tigris River in North Western part of Iraq; approximately $60 \mathrm{~km}$ northwest of Mosul city (Iraqi Ministry of Water Resources 2012) (Fig. 1). Mosul Dam is one of the most important strategic projects in Iraq for management of its water resources. Construction of Mosul Dam began on January 25th, 1981 and started operating on July 7th, 1986. The dam is a multipurpose project to provide water for three irrigation projects, flood control and hydropower generation. The dam is $113 \mathrm{~m}$ high and $3650 \mathrm{~m}$ long including the spillway. The top width is $10 \mathrm{~m}$ at the $341 \mathrm{~m}$ (a.s.l.) crest level. The dam is an earth fill type with a mud core. The upstream side is faced with rock (Iraqi Ministry of Water Resources 2012). The dam was designed to impound $11.11 \mathrm{~km}^{3}$ of water at the normal operation level, including 8.16 and $2.95 \mathrm{~km}^{3}$ of live and dead storage respectively (Fig. 2).

The dam has a concrete spillway located on the left abutment. The weir crest elevation of the spillway is $317.5 \mathrm{~m}$ (a.s.1.) and its length is $680 \mathrm{~m}$. The spillway has five radial gates measuring $13.5 \mathrm{~m} \times 13.5 \mathrm{~m}$ giving a discharge of $12,600 \mathrm{~m}^{3} \mathrm{sec}^{-1}$ at the maximum reservoir level of $338 \mathrm{~m}$ (a.s.l.) (Iraqi Ministry of Water Resources, 2012). The total cost of Mosul Dam estimated at 2.6 billion US\$ at the prices level of 1980s.

After impounding in 1986, seepage locations were recognized. The seepage due to the dissolution of 


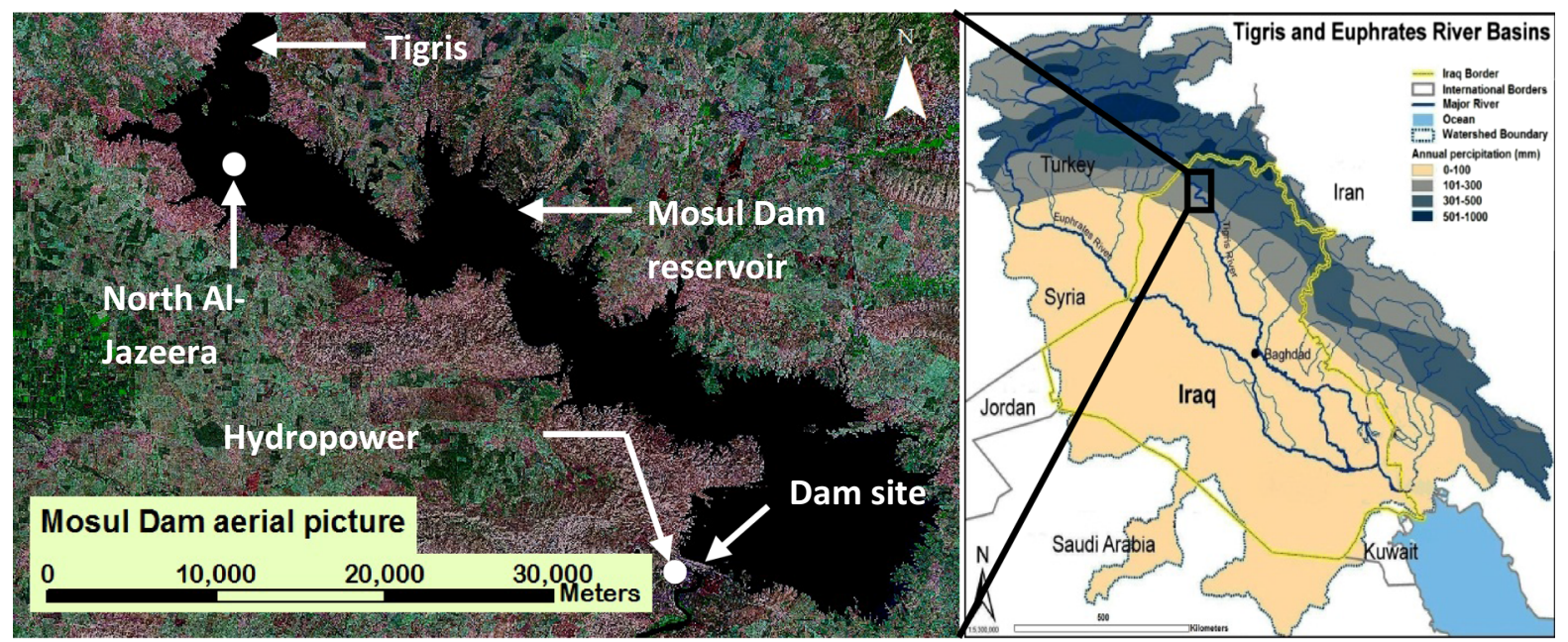

Fig. 1 Location of Mosul Dam with main facilities

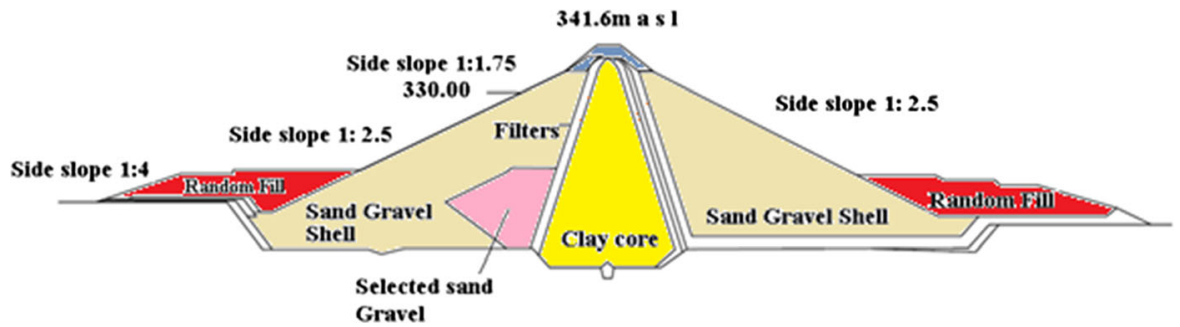

Fig. 2 Schematic diagram of Mosul Dam cross section

gypsum and anhydrite beds raised a big concern for the safety of the dam and its possible failure. In that winter as the reservoir level increased for the first time seepage began to appear from six major springs at the left bank downstream of the dam at different elevations. Seepage also occurred from under the dam in the deep river section which was discovered from observing the increase of sulphate concentration indicating gypsum leaching from the foundation rocks. The temporary downstream coffer dam used during diversion was raised and fitted with a measuring weir so to measure and sample the seepage from the deep river section. Results of seepage surveillance complete with salts concentration measurements were done from February 10, 1986 to August 16, Figs. 3 and 4 show the rise in reservoir water level and variation of measured seepage discharges at the different locations, Fig. 5 gives the change in transmissibility of the springs under the river section of the dam, and lastly Fig. 6 which shows the variation in dissolution rate of mineral salts. Analysis of these results yielded that

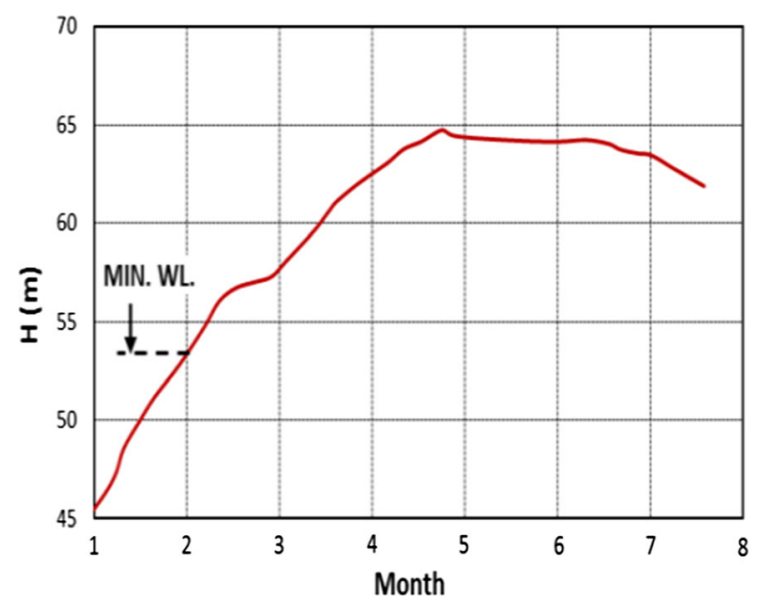

Fig. 3 Reservoir water level increase for the period FebruaryAugust (after Guzina et al. 1991)

13,000 tons of minerals were leached from the dam foundations at this period and that $70 \%$ of this quantity originates from the submerged springs. The dissolution intensity ranged from 42 to 80 t/day. It is very 


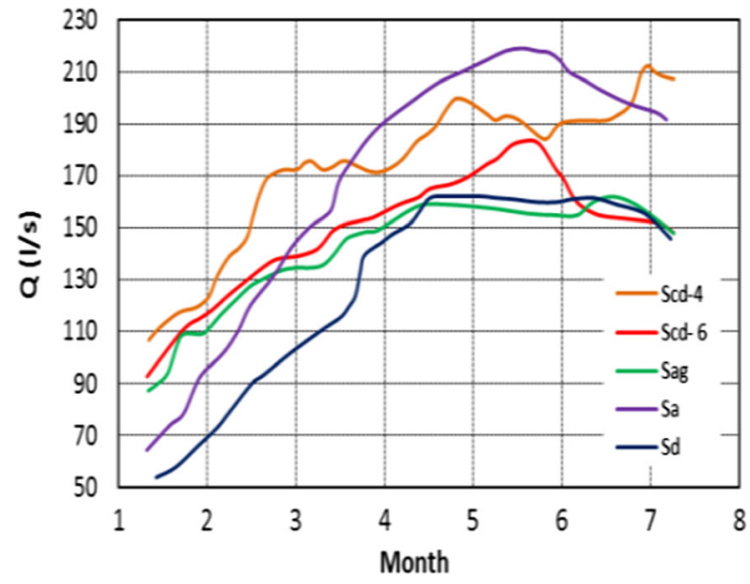

Fig. 4 Spring discharge variation for the period FebruaryAugust 1986(after Guzina et al. 1991)

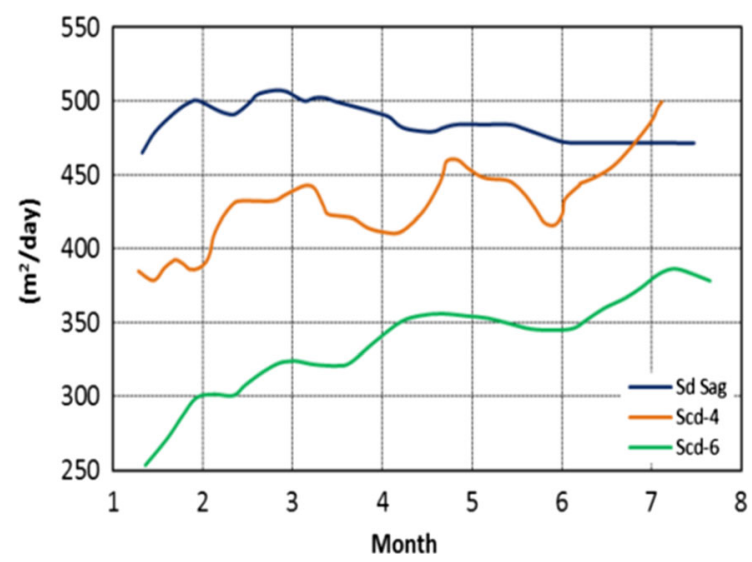

Fig. 5 Spring transmissibility change for the period FebruaryAugust, 1986 (after Guzina et al. 1991)

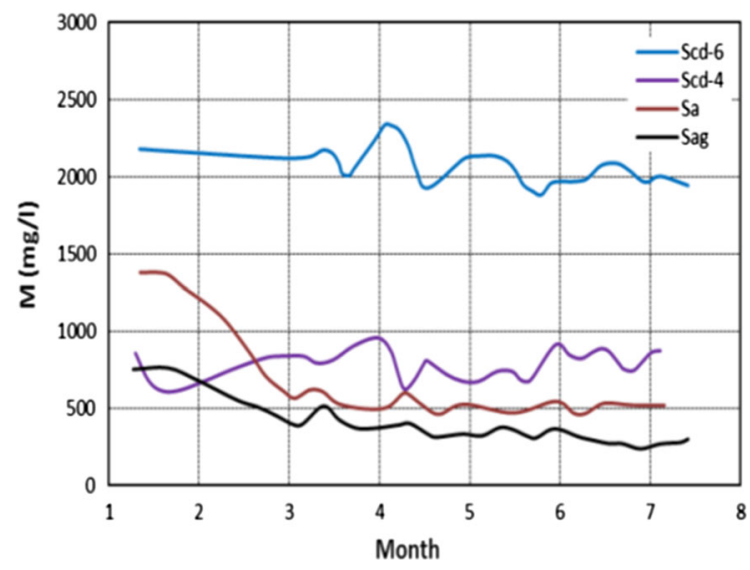

Fig. 6 Soluble salt concentration for the period FebruaryAugust, 1986 (after Guzina et al. 1991) clear from Fig. 6 that the dissolution rate of gypsum was very high as the reservoir was rising then the it decreased to reach a steady state after some time indicating that large quantity of salts were leached in the beginning from fissures and the crack's filling materials. Nevertheless, the final rates of dissolution were high which cause much concern.

It is unfortunate that all seepage measurements from under the dam in the river section were discontinued after at the beginning of filling the reservoir as the downstream temporary coffer dam was flooded by the back water from the reregulating scheme downstream. Measurements of seepage quantities from the left bank springs are still measured up till today but, results are not available to the authors. No seepage measurements were ever made in the grouting gallery as arrangements for such measurements were not envisaged. This problem was kept in a small closed circle within the Iraqi Ministry of Water Resources (previously Ministry of Irrigation) till the US Army Corps of Engineers conducted a study on Mosul Dam for the period June, 2004 to July, 2006 and highlighted the possibility of the dam failure. News media had highlighted this concern in 2014 when ISIS occupied the dam site area. It was reported that about 500,000 would lose their lives in case of Mosul Dam failure. Loses of property and destruction of the infrastructure of the main cities downstream the dam will be enormous, and it will reach the capital city Baghdad.

In this research, the main geological and engineering problems will be highlighted, and possible solution will be recommended.

\section{Geology of the Area}

In the vicinity of Mosul Dam, the exposed formation is Lower Fars (Fatha). It is composed of alternating beds of limestone, marl and gypsum (Al-Ansari et al. 1984). The dam abutments are located on the Upper Member of the Fatha Formation (Middle Miocene) (Fig. 7). The Upper Member, as the Lower Member of the Fatha Formation consists of cyclic sediments, marls, clay stone, limestone and gypsum; however, in the uppermost part the clay stone ratio increases as compared with the lower part. These inhomogeneous rocks; in their mechanical behavior will certainly behave differently when are loaded. The gypsum and 


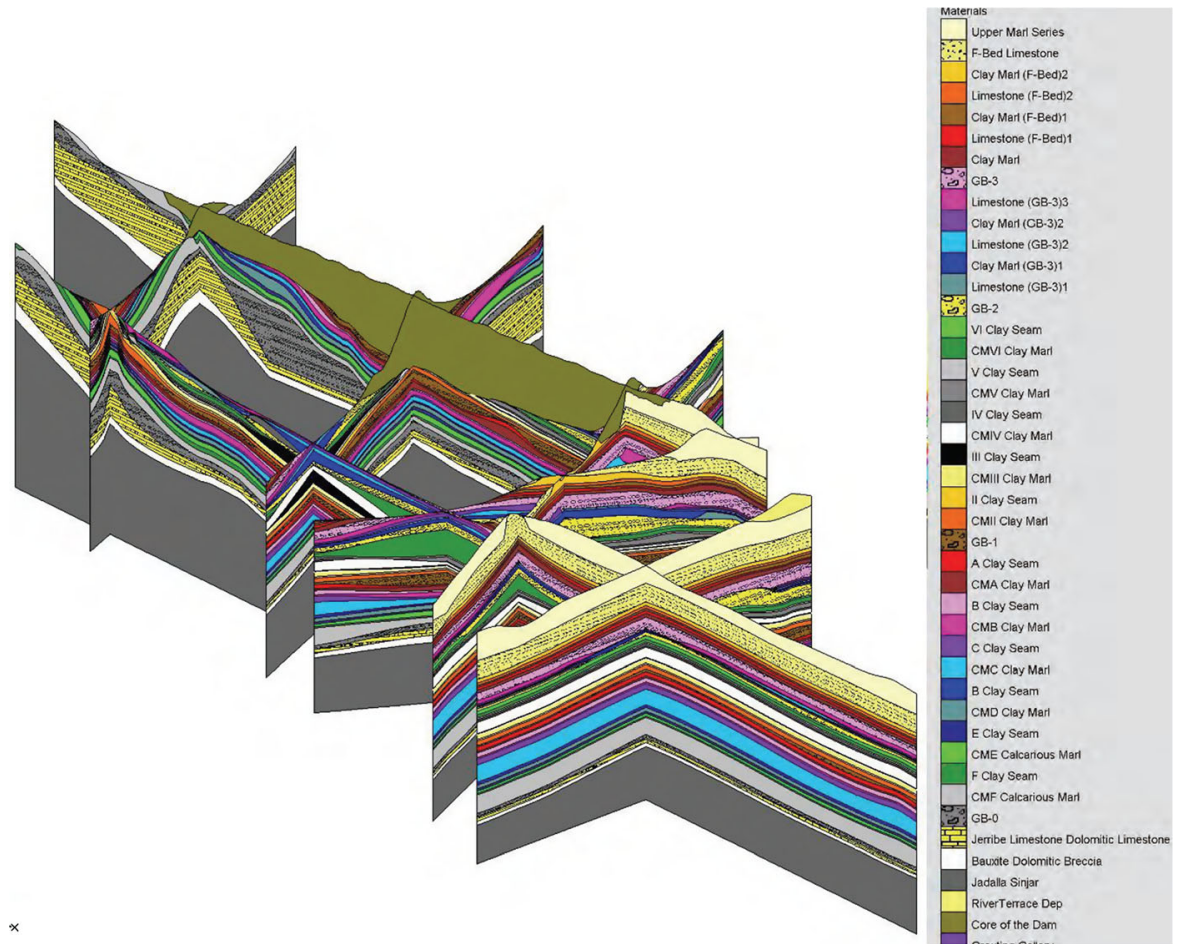

Fig. 7 Intersecting cross sections from intermediate version of ERDC geologic conceptual model, showing complex stratigraphy and partial resolution of discrepancies in stratigraphy at intersections of the geologic panels from generated boreholes. (Kelly et al. 2007)

limestone beds are usually karstified, but the karstification is less in the Upper Member as compared to Lower Member of the Fatha Formation (Sissakian 1978; Sissakian and Al-Musawi 2007). This is attributed to the presence of more clastics in the Upper Member than that of the Lower Member of the Fatha Formation, besides that gypsum and limestone beds become thin in the uppermost parts of the formation.

Due to the complexity of the geology of the area, several investigations were carried out (e.g. IVO 1969, Al-Sinjari 2007; Sissakian et al. 2014; Adamo et al. 2015a, b, c, d; Al-Ansari et al. 2015a, b, c, d; Sissakian et al. 2015; Adamo and Al-Ansari 2016a, b, c). AlAnsari et al. (1984) reported that there were two faults within the dam site area. The first is of rotational type striking NW-SE offsetting the northern corner of Butmah East structure. The other fault is trending $\mathrm{N}$ NE-S SW along the right bank of the River Tigris. This fault is not clear on the surface and it was detected using Landsat images. This is due to the fact that the fault is deep seated and it might be partly controlling the Tigris River course from the dam site to Aski
Mosul. Wakeley et al. (2007) collected all the borehole data and constructed a model to show the complex geology at the dam site (Fig. 7).

No tectonic activity is reported from the dam site and near surroundings (Sissakian et al. 2011). Furthermore, the present small faults, as discovered at the dam site during execution of detailed geological mapping by Iraq Geological Survey has no significant importance and/ or causes any hazard for the dam (Adamo et al. 2015a, b, c, d; Al-Ansari et al. 2015a, b, c, d; Sissakian et al. 2015; Adamo and AlAnsari 2016a, b, c). Therefore, the surface area of the dam site almost doesn't suffer from active tectonic disturbances; this is also confirmed by Kelly et al. (2007), when they stated that the dam body does not suffer from any problem.

\section{Geological and Engineering Problems}

The geology at the site has created a number of problems during construction, impounding and operation of the dam. After impounding in 1986, seepage 
locations were recognized. The cause of seepage is mainly due to geological problems that can affect the safety of the dam. These problems are:

- The karsts prevailing at the dam site and in the reservoir area.

- The existence of gypsum/anhydrite rock formations in the dam foundation alternating with soft marl layers and weathered and cavernous limestone beddings.

- The presence of an extensive ground water aquifer called Wadi Malleh aquifer which affects considerably the ground water regime in the right bank.

The most significant geological hazard that influences Mosul Dam is the karstification, especially in the foundation's rocks. The influence of the karstification is also confirmed by Swiss Consultants (1979), Al-Ansari et al. (1984), Black and Veatch (1984), Mark and Wheeler (2004), Sissakian and Ibrahim (2004), Washington International Group (2005), Hijab and Al-Jabbar (2006), Sissakian and Al-Musawi (2007), Hijab et al. (2007), and Sissakian et al. (2014). The karst development extends to a depth of $100 \mathrm{~m}$ below the foundation of the dam. The karstification enhanced the extensive dissolution of gypsum and gypsum anhydrite rocks present above and below the limestone layers. These dynamics caused the collapsing of whole layers of clayey marls into the underneath cavities forming beds composed of brecciated gypsum particles and anhydride blocks embedded into a loose clayey matrix. Four such layers were discovered during the geological investigations (Fig. 8). They have thickness, which ranged between 8 and $16 \mathrm{~m}$. The first layer was found at a depth of $80 \mathrm{~m}$ in the river section. The other three layers were at higher levels. One of these layers was discovered in the foundation of spillway chute ski jump. It proved to be very important due to their erratic behavior during the grouting of the deep grout curtain under the dam.

The presence of surface cracking and groundwater fluctuation give rise to the development of sinkholes. One sinkhole on the left flank of the reservoir appeared suddenly overnight in February 2003 and developed rapidly with $15 \mathrm{~m}$ of settlement and a $15 \mathrm{~m}$ diameter depression (Fig. 9). Other sinkholes appeared on the right side downstream the dam (Fig. 10). The rate of settlements of these sinkholes was $0.25 \mathrm{~m}$ when they appeared in 1992 and then it was reduced by $50 \%$ in
1998. The maximum cumulative settlement was recorded to be $5 \mathrm{~m}$ in the sinkhole SD4. It is believed that the formation of these sinkholes is due to the dissolution of surface gypsum beds which led to the formation of conduits under the surface. This took place due to the groundwater flow in Wadi Malleh aquifer toward the River Tigris where the recharge of this aquifer increased tremendously when the reservoir was impounded. The conduit has developed in size due to the fluctuation of the water level in the lake downstream the main dam caused by the operation of the regulating dam. Once the size of these caves increased and became closer to the surface it collapsed after heavy rainfall. Recent bathymetric survey conducted in 2011 showed the presence of a large number of sinkholes within the reservoir area (Fig. 11). This is a dangerous phenomenon where if these sinkholes are connected to Wadi Malleh aquifer it can cause numerous problems for the safety of the dam.

In addition, springs also appeared downstream the dam located on the same line of the sinkholes. The flow from the spring reached $360 \mathrm{l} / \mathrm{s}$ (Fig. 12). The water had high concentration of sulphate indicating its origin from Wadi Malleh aquifer (Swiss consultants 1984a). It should be mentioned, however, the amount of seepage flow from the Wadi Malleh aquifer was very high in the pumping storage scheme and the tailrace tunnel and its intake structure. The excavation of the caverns was only possible after performing extensive grouting works all around these caverns. The importance of the Wadi Malih aquifer is not only due to the great difficulties it caused during the construction of the pump storage scheme; but also that it shapes the ground water flow regime in and around the right abutment of the dam in addition to the fact that it contributed to the formation of a series of sinkholes at the right bank downstream of the main dam. The high concentration of sulphate in the water of this aquifer clearly indicates the dissolution of gypsum from the dam site and its vicinity. In addition, the hydrostatic pressure of water within the reservoir in increasing the rates of dissolution. This process is in progress since the operation of the dam. This process also led to the appearance of other features like the fissure near $100 \mathrm{~m}$ from the right abutment of the dam which appeared in 1996 (Fig. 13). Furthermore, the dissolution phenomena continued into later years. Figure 14 shows a large conduit which was discovered 


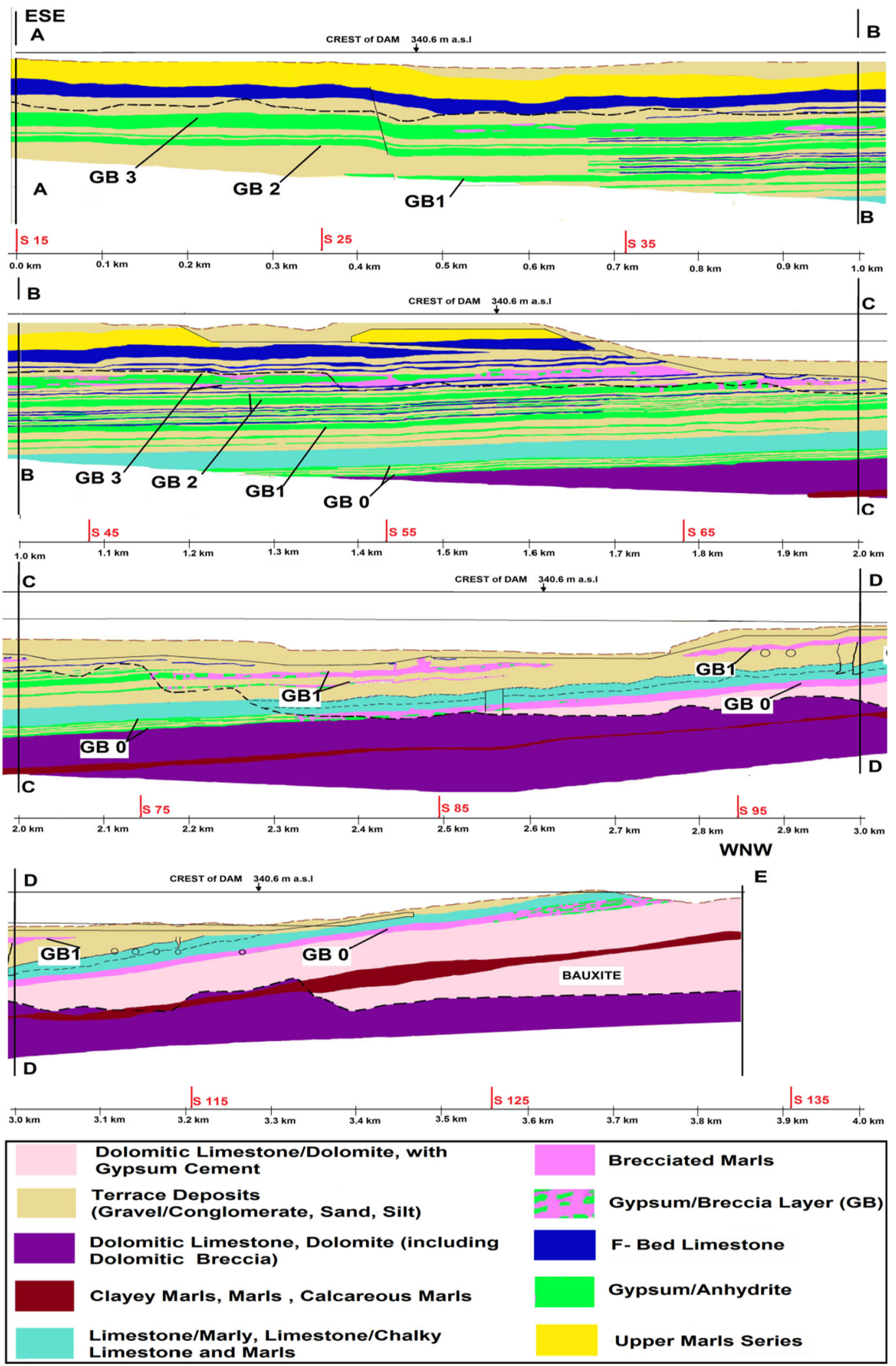


4Fig. 8 Geological Cross Section along the axis of the dam

in March 2002 within a gypsum/anhydrite layer on the right side of the reservoir.

In view of the above, it can be clearly stated that there are a dynamic movement of groundwater within the dam site and it's surrounding causing high rates of dissolution of gypsum associated with washing fine clay and carbonate small particles. This process is alarming where it can create large caves that can reach the surface of the ground leading to sudden collapse of the ground surface during the infiltration of surface water through the top cover of these caves. This was noticed in February 2003 (see Fig. 9), October 2004 and July 2005. This phenomenon is old within the karstified rocks of the area and has been increasing in its rate due to the effect of the operation of the dam (Adamo et al. 2015a, b, c, d; Al-Ansari et al. 2015a, b, c, d; Sissakian et al. 2015; Adamo and AlAnsari 2016a, b, c).

\section{General Status of the Geological Conditions}

To evaluate the status of the geological conditions in the dam area, the Engineer's and Environmental center of research of the US Army Corps of Engineers (Kelly et al. 2007) used the rock quality designation (RQD) (Deere and Deere 1989) as an index for the description of rock mass fractured state. This test was performed on samples taken in 1989 and 2006. The results showed that RQD was $45-65 \%$ and $0-20 \%$ for the two years respectively. The deterioration of the samples is due to the dissolution of gypsum.

In addition, the deep curtain grouting was also investigated. It was noticed that some parts were highly deteriorated and required grouting 4 or 5 times annually. It was also noticed that the dissolution front
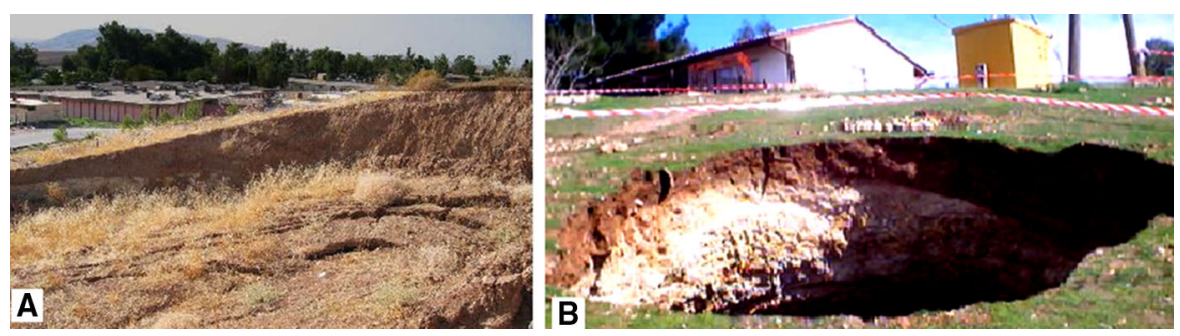

Fig. 9 The left bank sinkhole a early stage $\mathbf{b}$ full development stage

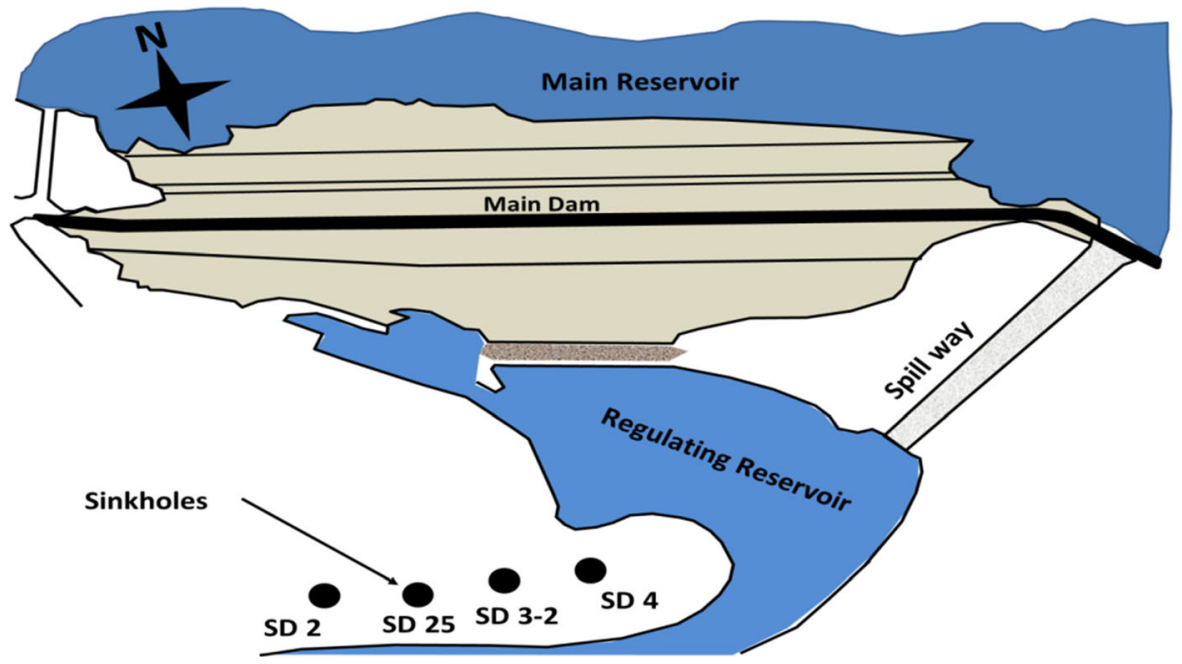

Fig. 10 Sinkholes downstream Mosul Dam-Right Bank 


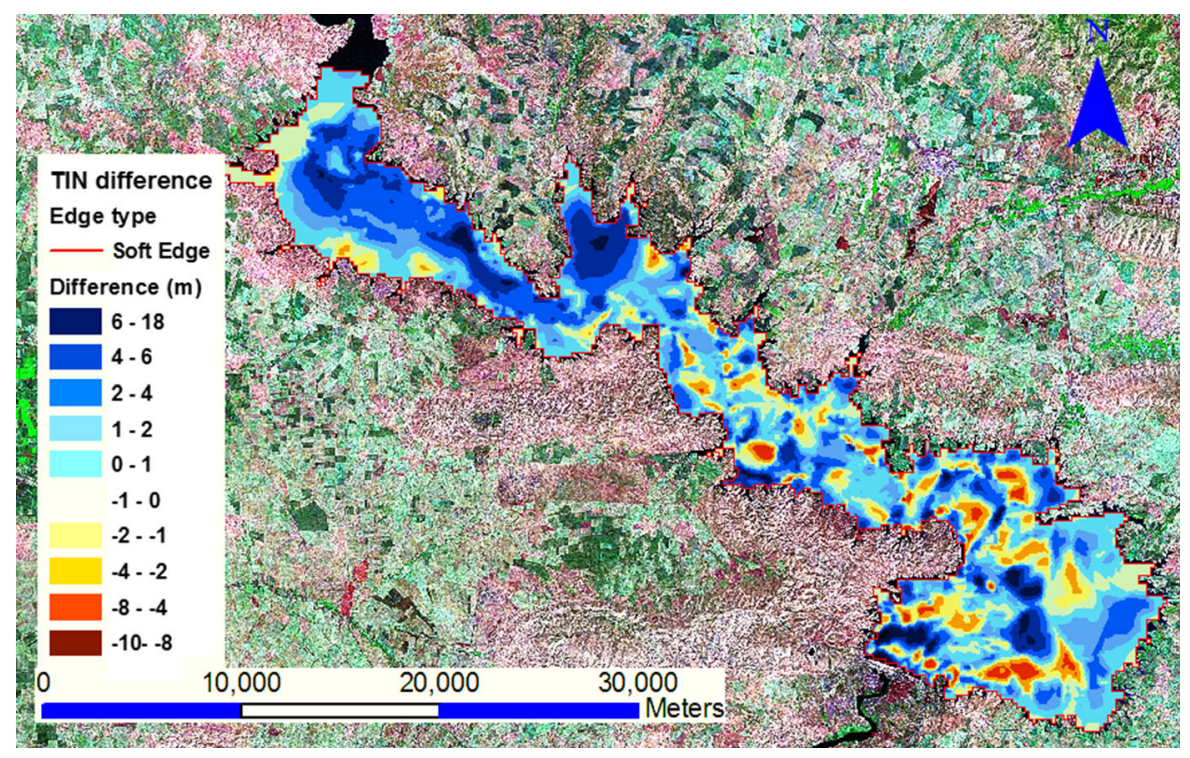

Fig. 11 Holes noticed at the bed of Mosul reservoir (Issa et al. 2013)

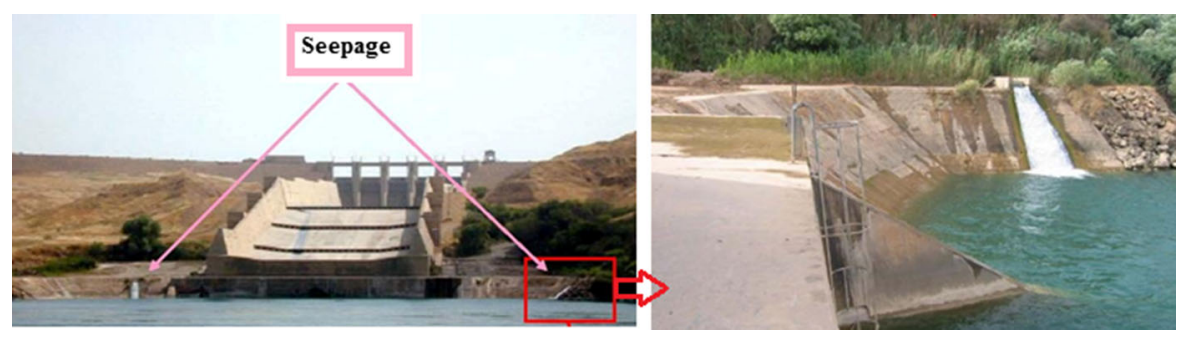

Fig. 12 Example of seepage

Fig. 13 Fissure on the right slope side of the dam

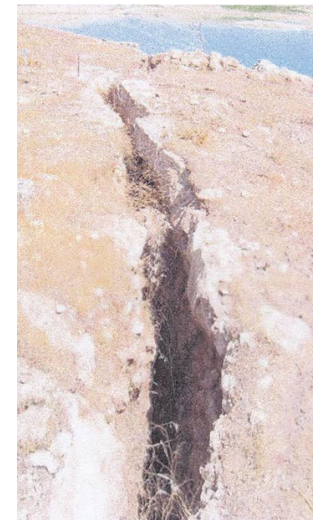

had progressed $350 \mathrm{~m}$ toward the east i.e. an average of about $17 \mathrm{~m} /$ year. The samples recovered from the grouting gallery showed that all the rocks were replaced by friable grout material.

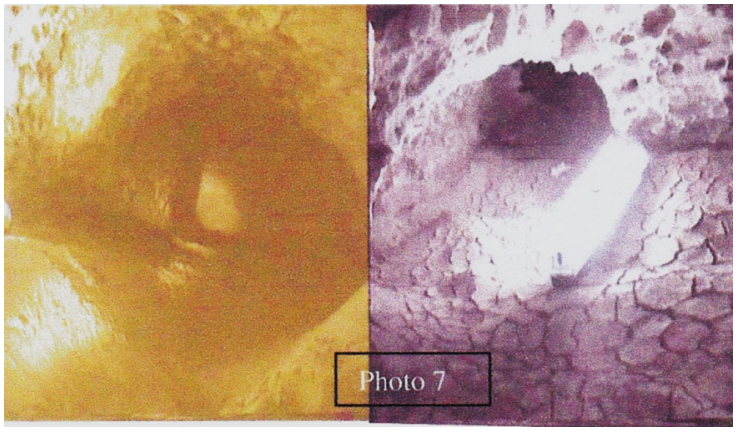

Fig. 14 Large conduit found in March 2002 in the upper right rim of the reservoir

Taking this information into consideration, the following points can be highlighted.

- The dissolution phenomenon is not recent in Mosul Dam area. The impounding of Mosul Dam reservoir increased the rate of dissolution of the rocks. 
This had led to the sudden appearance of sinkholes in the area.

- The bedding plains under the foundation of the dam represent weak areas which had eased the water movement along these surfaces. The movement of water along these surfaces increased the dissolution of rocks vertically and horizontally. Furthermore, the supply of fresh unsaturated water from Mosul Dam reservoir tremendously increased this process.

- The dip of the beds on the eastern side of the dam that does not exceed 6 degrees SE direction and this makes the groundwater to move along this direction. It was noticed that when the water level in the reservoir exceeds $318 \mathrm{~m}$. a. s. 1. the rate of dissolution increases. This is attributed to the rock types within the area. The beds on the far East part of the dam are horizontal and that condition decreases the rate of dissolution. It should be also mentioned that the high dip of beds on the right side of Wadi Deer Almaleh fold is so high and this reduces the rates of dissolution.

In view of the above, it is obvious that the situation of the dam is deteriorating with time. On the 8th of August, 2014, the Islamic State of Iraq and Syria (ISIS) terrorists group seized control of the Mosul Dam and it was seized back from the hands of ISIS on the 16th of the same month. The end result of all this was the halting of the grouting operations which had continued for the past 30 years and had consumed more than 95,000 tons of solid grouting materials which were considered, even if temporary solution, the only one necessary to stabilize the foundation for some more time. Then, in 2015, many United States agencies were led by the USACE to carry out measurements, surveys and observations to follow developments that might lead to the dam failure. The findings of the team were:

The concentration of sulfates in the seepage water increased indicating increased dissolution of gypsum.

Caverns and sinkholes are increasing under the dam. There were signs of increased formation of cavities under the dam. Dissolution of gypsum reached $10,000 \mathrm{~m}^{3}$ during the period August 2014 until beginning of 2016 due to discontinuation of grouting works.
Increased monolith movement in the grouting gallery and cracks opening were noticed.

It was a very well known fact to the Engineers working in the dam that there was continuous settlement in the grouting gallery under the dam which is beyond the expected elastic compression values. This indicated that even with the continuous grouting under the foundation for all the past years, dissolution of gypsum continued making room for these high settlements. Records were kept and plotted from 1986 up to summer of 2015. The plot in Fig. 15 shows this settlement in five locations along the grouting gallery in the deep section of the dam.

(Al-Abayachi 2016, p. 12). The movements are believed to be caused due to settlement and not resulting from onsite activity. Cumulative settlement in the grouting gallery from 1986 to the end of 2015 records showed a sharp increase in settlement in 2015 which indicates a worsening situation in the dam foundations (Al-Abayachi 2016, p. 13). Satellite based information also indicated that there are local differential settlement in the body of Mosul Dam averaging from 5 to $10 \mathrm{~mm} /$ year (Coffman 2014; Cetinic 2016). In December 2016, Milillo et al. published their findings from space geodetic monitoring of Mosul Dam. They found that the rate of subsidence of Mosul Dam for the period 2004-2010 was $12.5 \mathrm{~mm} /$ year has increased to $15 \mathrm{~mm} /$ year after 2013 after re-grouting operations stopped (Fig. 16). This subsidence is related to the dissolution of gypsum and the reservoir-induced pressure which is the main cause of an increase in the dissolution rates. They also added that any annual increase of water levels in the reservoir in the future could lead to an increase of water pressure in the dam foundation, which combined with the absence of regrouting could speed up the dissolution of the dam substrate and promote its destabilization.

The plot of the data for Mosul Dam on the screening Portfolio Risk Analysis (SPRA) process for Dam Safety is shown in Fig. 17. This plot considers loading frequency, an engineering rating to estimate a relative probability of failure, and both human life loss and economic consequences of failure (MaCleanathan 2009; U.S. Department of the Interior Bureau of Reclamation 2014). This procedure shows that Mosul Dam is in a state of extreme relative risk (Fig. 17). For more details see Adamo et al (2015a, b, c, d); Al- 


\section{Gallery Settlement Plots}

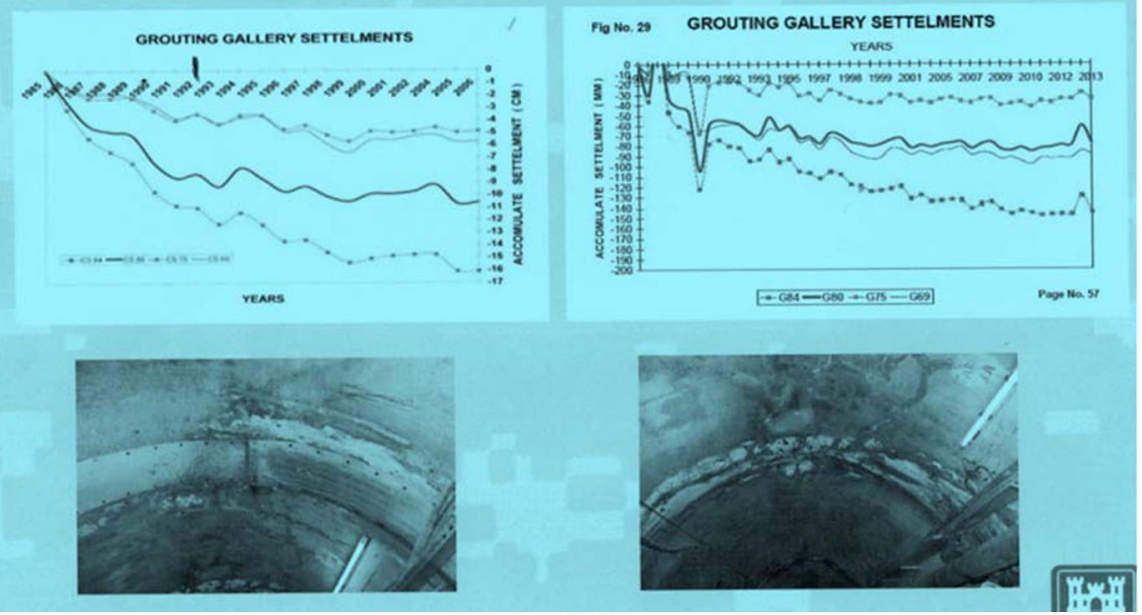

Fig. 15 Cumulative settlements in five locations in the grouting gallery (Al-Abayachi 2016)
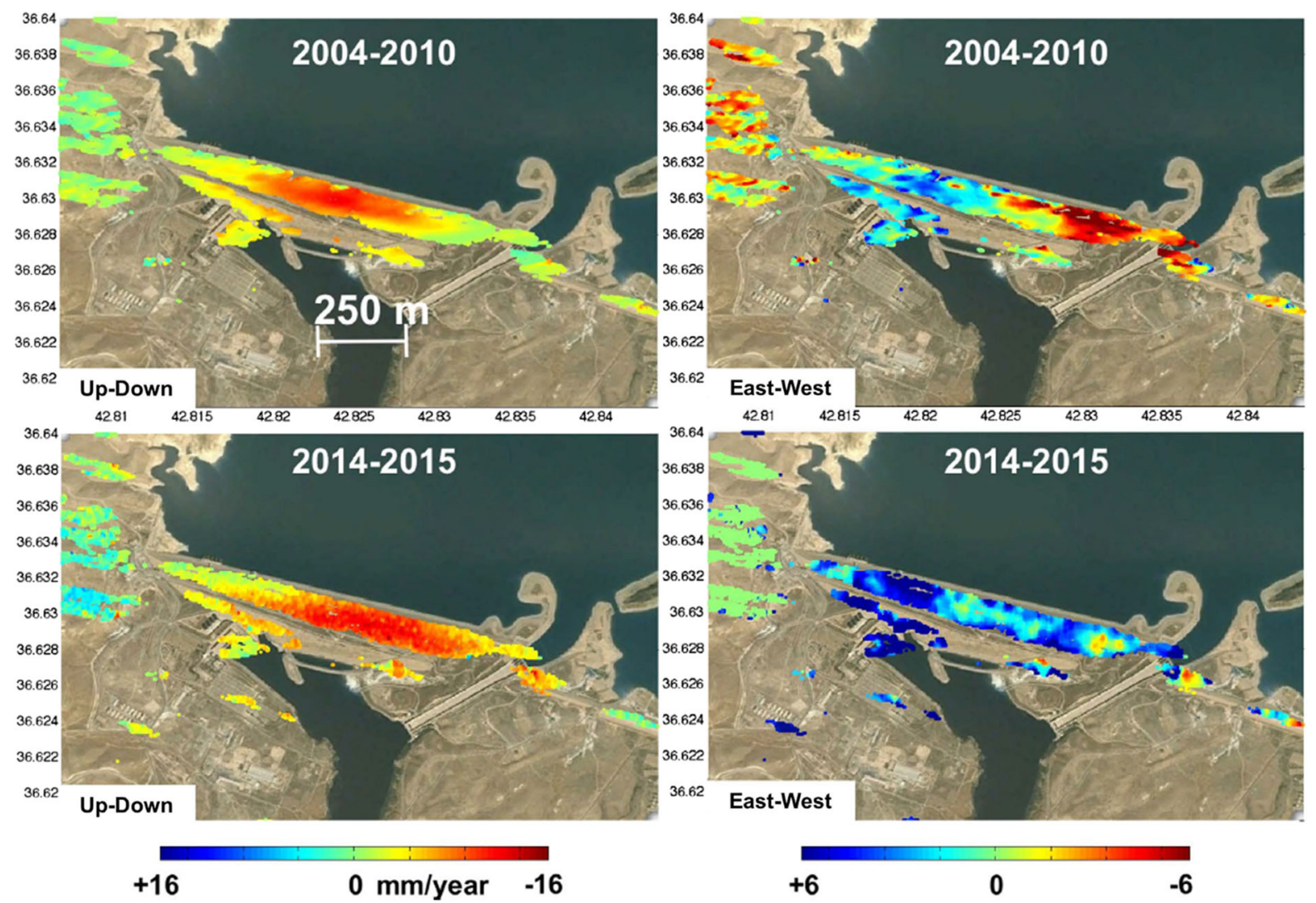

Fig. 16 Up-down (left) and east-west (right) displacement at the Mosul dam, Iraq. Negative values indicate downward and westward motion respectively (Millillo et al. 2016) 


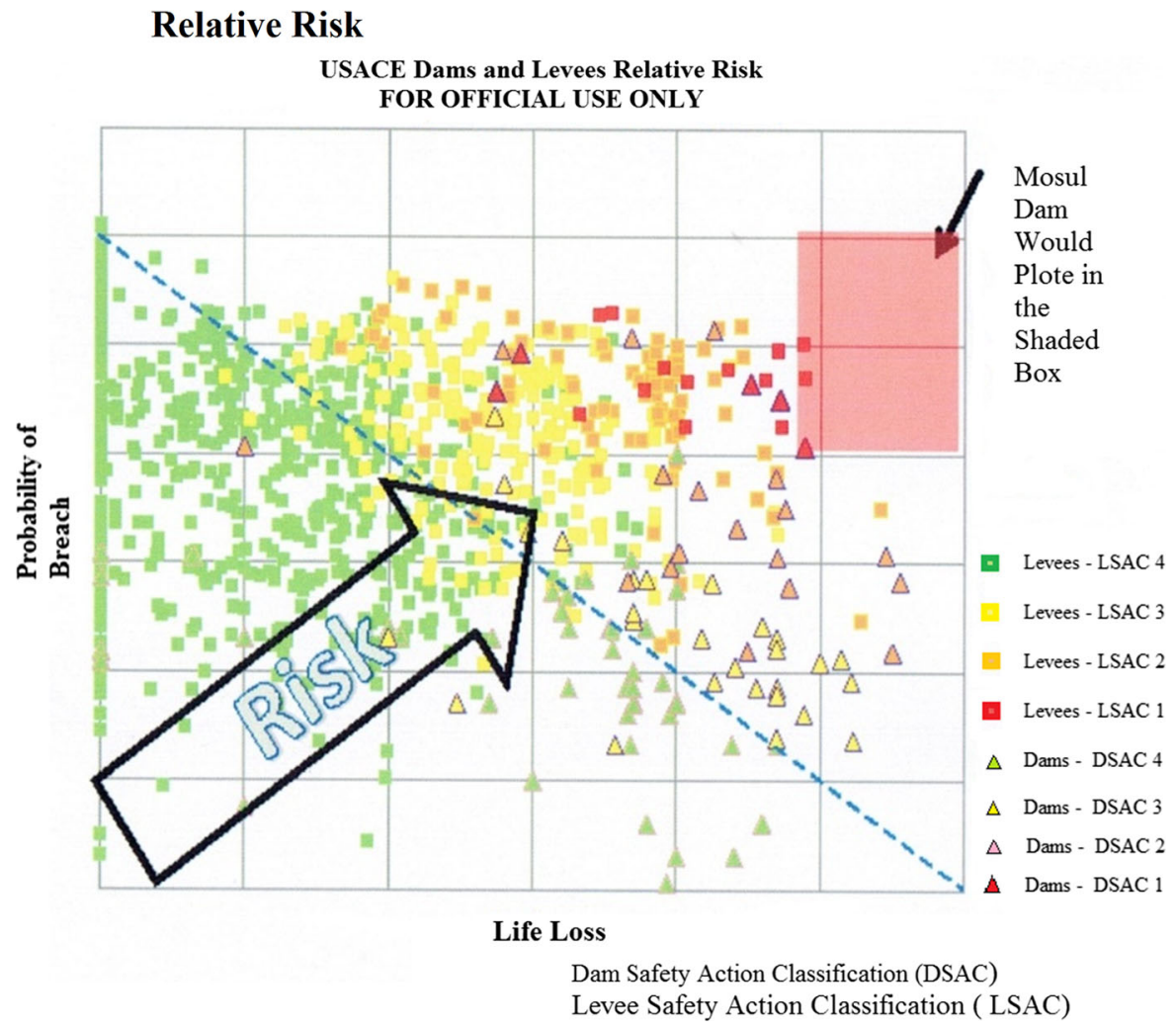

Fig. 17 Screening Portfolio Risk Analysis (SPRA) for Mosul Dam (after Al-Abayachi, 2016)

Ansari et al. (2015a, b, c, d); Sissakian et al. (2015) and Adamo and Al-Ansari (2016a, b, c).

\section{What Happens if the Dam Fails?}

In 1984, the Ministry of Irrigation commissioned the Swiss Consultants Consortium to carry out a potential dam break and flood wave study for Mosul Dam. The study was completed in three volumes report which contained the possible causes of failure, full description of the mathematical model used, its calibration using known high flood recordings, and a complete flood routing of the wave in its way in the Tigris river valley down to (24) kilometers south of Baghdad (Swiss Consultants 1984c, d, e). Swiss consultant considered that if failure would occurs; the most plausible cause would be piping in the foundation resulting in enlarged flows within the dam base which would progress to open a big gap in the dam. The model used in the simulation was (Flow in River Systems) best known as (FLORIS). The calibrating of the model showed that it fits best the recorded floods when manning (n) used was (0.030). For a flood wave of the size under consideration the consultant adopted rightly a value of (n) equals (0.033), and even checked what could happen if (n) is (0.050). For gap width two values were considered; $700 \mathrm{~m}$ and $200 \mathrm{~m}$ respectively. The first value being the more plausible one as it is equal to the length of the dam section closing the river channel, while the second is in line with the Corps of Engineers practice of considering a gap width double the dam height. Six scenarios were run to get the hydrographs of the Flood wave for these scenarios. The results are shown in Table 1 which is constructed from the tables and hydrographs given in the original study (Swiss Consultants 1984c, d, e) and published in reference (Adamo and Al-Ansari 2016c).

From the above table it can be seen that the initial maximum discharge of the wave may vary between $\left(551000 \mathrm{~m}^{3} / \mathrm{s}\right.$ to $\left(415000 \mathrm{~m}^{3} / \mathrm{s}\right)$ according to the scenario under consideration. FLORIS was then used to route the wave all the way down to Baghdad for different possible water levels in the reservoir. Table 2 
Table 1 Flood Hydrograph in the first (24) hours of dam collapse (Swiss Consultants 1984d)

\begin{tabular}{|c|c|c|c|c|c|c|}
\hline Case & 1 & 2 & 3 & 4 & 5 & 6 \\
\hline Manning "n” & 0.033 & 0.050 & 0.033 & 0.050 & 0.033 & 0.050 \\
\hline Width of Breach $(\mathrm{m})$ & 700 & 700 & 700 & 700 & 200 & 200 \\
\hline Breaching time (h) & 4 & 4 & 5 & 5 & 2 & 2 \\
\hline Time in hours (h) & \multicolumn{6}{|c|}{$\mathrm{Q} \times 1000 \mathrm{~m}^{3} / \mathrm{s}$} \\
\hline 0 & 1 & 1 & 1 & 1 & 1 & 1 \\
\hline 1 & 13 & 13 & 13 & 13 & 50 & 50 \\
\hline 1.5 & 80 & 80 & 80 & 80 & 385 & 380 \\
\hline 2.0 & 215 & 210 & 215 & 212 & 425 & 415 \\
\hline 2.5 & 372 & 356 & 335 & 325 & 405 & 390 \\
\hline 3.0 & 474 & 452 & 422 & 404 & 385 & 365 \\
\hline 3.5 & 535 & 499 & 480 & 453 & 375 & 330 \\
\hline 4.0 & 551 & 510 & 509 & 475 & 360 & 310 \\
\hline 4.5 & 538 & 469 & 497 & 460 & 345 & 290 \\
\hline 5.0 & 507 & 469 & 497 & 460 & 330 & 275 \\
\hline 6.0 & 405 & 382 & 435 & 405 & 280 & 260 \\
\hline 8.0 & 271 & 266 & 186 & 278 & 205 & 210 \\
\hline 10.0 & 186 & 192 & 195 & 198 & 180 & 160 \\
\hline 12.0 & 123 & 136 & 130 & 142 & 150 & 80 \\
\hline 18.0 & 37 & 47 & 39 & 49 & 50 & 65 \\
\hline 24.0 & 18 & 2 & 19 & 22 & 20 & 40 \\
\hline
\end{tabular}

shows the peak discharges of the wave, its heights, and times of arrival at the different cities and towns along the river course.

This study was checked by Black \& Veatch in 2005. They outlined their conclusions in their report (Washington Group and Black and Veatch 2005). Their method was to decouple the derivation of the breach development hydrograph from routing the wave in the river channel. For the first part they used the model (DAMBRK UK) upgraded to fit UK conditions by Binnie and Partners and the University of Bradford, and they indicated that the output could be fed to any of the two models (ISIS 2.2) developed by (HR Wallingford) and Halcrow (UK) or (MIKE 11) developed by the Danish Hydraulic Institute in order to carry out the wave flood routing. Both models had the capability of presenting the results in graphical form and interfacing with GIS to provide details of impounded area. As a final judgment (Black \& Veatch) considered that both models did not add to the accuracy of the results in the Swiss Consultants using (FLORIS) and any additional output did not justify the additional work needed to apply any of these two models, so they accepted using (FLORES) for the flood wave routing. They considered finally that SC study was done in the best possible way and in highly professional manner. Later on in (2009) and (2015) two more studies on the subject were done namely (Al-Taiee and Rashed 2009) and (Mahmud et al. 2015). In these studies, they used other models for the analysis but in using these models they assumed gap width and time of gap breach without giving justification of the selected values. Their assumption of (n) value seemed also to be far from the real conditions. In addition to all this no mention was given on how the calibration of their models and its validation were done. These missing details result in many question marks and may shed doubt on the outcome of these studies.

A new study was performed by (Annunziato et al. 2016) from the Joint Research Center of the European Commission (JRC. They investigated the time evolution and characteristics of the flood wave and its impact on the population living along the Tigris River. The (HyFlux2) computer code was used and which had been developed at the center by Franchello and Krausmann (2008). This model was routinely used for tsunami and storm surge events but originally developed for dam break analysis problems. Table 3, summaries the results of the studied scenarios for 
Table 2 Wave peak discharges, its heights, and time of arrival to selected points along the river (Swiss Consultants 1984d)

\begin{tabular}{cccccc}
\hline Location & $\begin{array}{c}\text { Distance } \\
(\mathrm{km})\end{array}$ & $\begin{array}{c}\text { Discharge } \\
\text { x } 1000 \\
\left(\mathrm{~m}^{3} / \mathrm{sec}\right)\end{array}$ & $\begin{array}{c}\text { Wave } \\
\text { Height }(\mathrm{m})\end{array}$ & $\begin{array}{c}\text { Time of } \\
\text { Arrival }(\mathrm{hr})\end{array}$ & Remarks \\
\hline Dam Site & 0 & 551 & 54 & 0 & \\
Regulating Dam & 9 & 545 & 48 & 1.3 & \\
Eski Mosul & 17 & 481 & 45 & 1,6 & \\
Mosul City & 69 & 405 & 24 & 4 & \\
Hammam Ali & 97 & 370 & 18 & 5 & Backwater extends 10 km.in the \\
Upper Zab C. & 225 & 345 & 20 & 7 & Tigris and 15 km.in the upper Zab. \\
& & 310 & & & Wave height value is average \\
Backwater extends 25 km. in the \\
Lower Zab C. & 330 & 250 & 25 & 13.5 & Tigris and 20 km. In the Lower \\
& & 210 & & & Zab. Wave height value is average \\
The drop in wave height is 13 & meters in short distance \\
Makhool Range Narrows & 361 & 361 & 30 & 16 & \\
Tikrit & & 195 & 17 & & \\
Sammara & 422 & 185 & 15 & 22 & \\
Balad & 479 & 162 & 10 & 25 & \\
Khalis & 516 & 115 & 9 & 28 & \\
Tarmiya & 566 & 81 & 6 & 31 & \\
Baghdad ( North) & 597 & 72 & 4 & 33 & \\
Baghdad Center) & 638 & 46 & 4 & 38 & \\
Baghdad (South) & 653 & 35 & 4 & 44 & \\
Diyala C. & 674 & 34 & 3.5 & 48 & \\
Salman Pak & 708 & 34 & 3 & $>48$ & \\
\hline
\end{tabular}

Note: numbers in colored areas show the wave discharges and height at the beginning and end of the backwater curves created at the Upper Zab and Lower Zab confluences with Tigris and also at the narrows through Makhool ridge crossing the river

different reservoir levels and assuming bottom of the breach at level (252), breach area equals $(26 \%)$ of the dam surface area, i.e. $40,560 \mathrm{~m}^{2}$ out of $155,000 \mathrm{~m}^{2}$. This table gives the peak height of the wave, time of arrival of the wave and time of arrival of its peak to five cities along the river. Accordingly, the wave will reach Mosul city after 1 h. $40 \mathrm{~min}$. and Baghdad in 3.5 days. The maximum height will be about (26) meters and (8) meters in Mosul and Baghdad respectively. Figure 18 gives the wave peak height at five cities and its arrival time.

From LANDSAT 2014 Global population Database and the STRM91 and topography layers with resolution of $1 \mathrm{~km}^{2}$, the researchers arrived at the number of affected population at different depths of inundation. This was done by superimposing water depths of $(0.1 \mathrm{~m}, 0.5 \mathrm{~m}, 2.0 \mathrm{~m}, 5.0 \mathrm{~m}, 10 \mathrm{~m}$ and. $>10 \mathrm{~m})$ on the (LANDSAT 2014) global population database to find the number of people between these levels. The study arrived at a very interesting statistics which is shown in Table 4.This table shows total number of population and total areas affected for a scenario of reservoir water level of (330) which is the maximum reservoir design operation level.

From tables presented in this study Table 5 was also constructed. It gives the number of population affected at various reservoir water levels (RWL), for different periods $(\mathrm{T})$ and at different depths of inundation at the five biggest cities along river course shown. The scenarios of failure are:

- Reservoir water level $=330$ which is the maximum design operation water level.

- Reservoir water level $=319$ which the maximum operation water level adopted in (2006).

- Reservoir water level $=300$ which is the dead storage water level as per design. 
Table 3 Values of wave time arrival, time of wave peak arrival and the maximum height of wave for various scenarios (Annunziato et al. 2016)

\begin{tabular}{|c|c|c|c|c|c|c|c|c|c|c|c|c|c|c|c|}
\hline \multirow{2}{*}{$\begin{array}{l}\text { City } \\
\text { RL }\end{array}$} & \multicolumn{3}{|c|}{ Mosul } & \multicolumn{3}{|l|}{ Baeji } & \multicolumn{3}{|l|}{ Tikrit } & \multicolumn{3}{|c|}{ Sammara } & \multicolumn{3}{|c|}{ Baghdad } \\
\hline & $\mathrm{T}_{1}$ & $\mathrm{~T}_{2}$ & $\mathrm{H}$ & $\mathrm{T}_{1}$ & $\mathrm{~T}_{2}$ & $\mathrm{H}$ & $\mathrm{T}_{1}$ & $\mathrm{~T}_{2}$ & $\mathrm{H}$ & $\mathrm{T}_{1}$ & $\mathrm{~T}_{2}$ & $\mathrm{H}$ & $\mathrm{T}_{1}$ & $\mathrm{~T}_{2}$ & $\mathrm{H}$ \\
\hline 330 & 1.7 & 6.2 & 26.3 & 16,8 & 23.5 & 14.3 & 21.08 & 26.8 & 14.5 & 26.12 & 30.08 & 16.1 & 67.0 & 67.0 & 8 \\
\hline 319 & 2.29 & - & 22.7 & 18.59 & - & 11.8 & 24.07 & - & 11.8 & 30.05 & - & 13.8 & 76.20 & - & 7.6 \\
\hline 309 & 2.55 & - & 19.2 & 22.54 & - & 9.3 & 29.00 & - & 9.5 & 36.48 & - & 11.1 & 96.40 & - & 7.5 \\
\hline 307 & 2.54 & - & 18.6 & 23.45 & - & 8.9 & 30.04 & - & 9.1 & 38.12 & - & 10.4 & 103.05 & - & 7.4 \\
\hline 305 & 3.17 & - & 17.9 & 24.53 & - & 8.3 & 31.19 & - & 8.7 & 40.12 & - & 9.9 & 111.31 & - & 7.3 \\
\hline 300 & 3.40 & - & 16.0 & 28,32 & - & 7.3 & 35.58 & - & 7,8 & 46.18 & - & 8.3 & 141.33 & - & 7.1 \\
\hline
\end{tabular}

$R L$ Reservoir water Level (m.a.s.1.), $T 1$ Time of wave arrival (h), T2 Time of wave peak arrival (hours), $H$ Maximum wave height (meters)

From all these statistics it can be concluded that If Mosul Dam fails then the catastrophe which follows is by far beyond anything which had been experienced before or can be imagined to happen in the future.

\section{Is There a Possible Solution?}

Since the start with the seepage problem, number of solutions was discussed to overcome the problem. The International Board of Experts (IBOE) which was appointed by the Ministry of Irrigation at that time to follow the designs and the construction of the dam. IBOE had number of meetings with the designers and contractors discussing the problems at the dam site. Reports and studies submitted by other consultants and experts who were invited by either the Contractors, or the Board and the Owner were also discussed during these meetings. Grouting problems and type of grout mixture were discussed. Recommendations to use silica gel in the grouting of the left bank curtain in order to reduce seepage appearing in the left bank and very high takes of cement grouts and the use of sand gravel mixes in a number of zones were also considered (see Lga 1986; Binnie and Partners 1987). All studies concluded that the dissolution of rocks that had occurred since impounding was substantial, but not so great as to preclude a successful completion.

Several alternatives were suggested. These were:

a. Precipitation of insoluble materials (such as sodium chloride) from ground seepage water to fill seepage paths. Since the precipitant

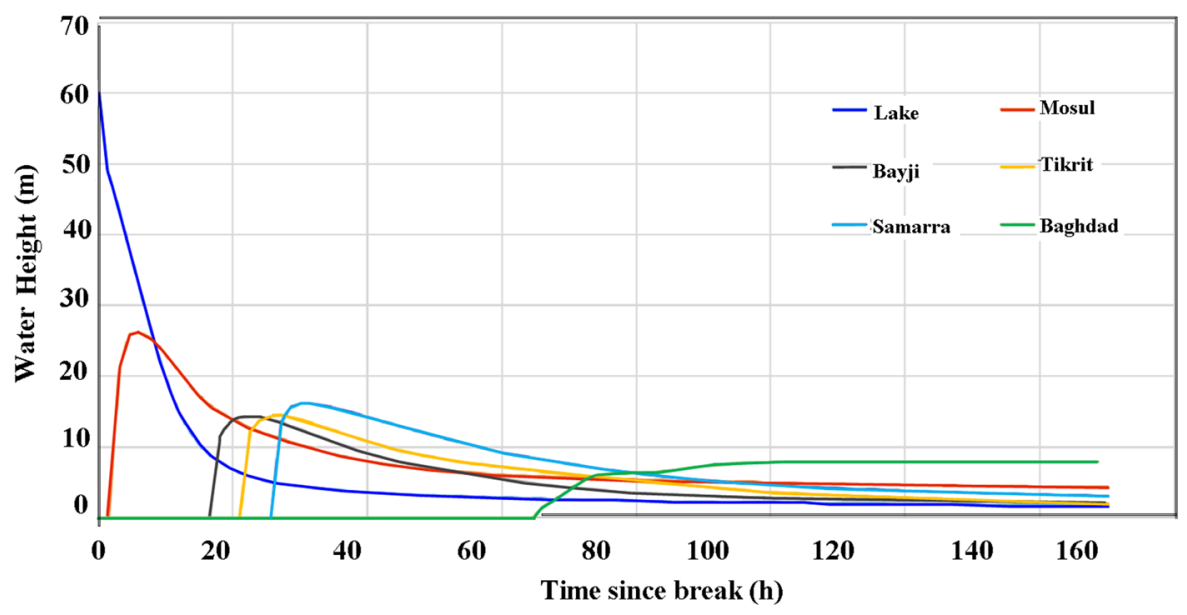

Fig. 18 Mosul Dam Break: Height-Time graph (Annunziato et al. 2016) 
Table 4 Number of People affected and areas inundated at various water depths of flood water for reservoir water level (330) (Annunziato et al. 2016)

\begin{tabular}{lrc}
\hline Inundation & Population & Area $\left(\mathrm{km}^{2}\right)$ \\
\hline $0.1-0.5 \mathrm{~m}$ & 948,000 & 637 \\
$0.5-2.0 \mathrm{~m}$ & $3,144,000$ & 2022 \\
$2-5 \mathrm{~m}$ & $1,626,000$ & 1150 \\
$5-10$ & 260,000 & 916 \\
$>10 \mathrm{~m}$ & 270,000 & 916 \\
Total & $6,248,000$ & 7202 \\
\hline
\end{tabular}

volume will not be enough to fill seepage paths of various sizes and that the injected fluid may flow in an unpredicted manner by varying seepage flows, this was rejected.

b. Protecting gypsum or anhydrite surfaces against dissolution by sealing gypsum/anhydrite surfaces. This can be achieved either by maintaining a saturated or super saturated solution with $\mathrm{SO}_{4}$ against the rock surfaces, which requires a continuous supply of solution to seepage water probably from an upstream gypsum blanket. This was rejected due to large quantities of removed gypsum daily from the foundation and the uncertainty of directions taken by seepage flow path. The other alternative was to provide a chemical solution, which react with $\mathrm{CaSO}_{4}$ to form a highly insoluble coating. This suggests the use of calcium oxalate, but the problem facing this solution is the tenacity and durability of such a coating against further seepage and the uncertainty and difficulties of judging the performance with time. In addition, this material is toxic effects of oxalate to animals and humans and the large volumes required to be released into ground water.

c. Use of barriers: This can be achieved by:

i. Blanketing: Blanketing the upstream side of the dam and reservoir (Fig. 19). This is normal done by drawing down the reservoir and to avoid this, dropping the lining materials (bentonite pellets) through pipes lowered into the bottom of the pond then sand is placed on top to hold the clay in place against any disturbances. This method has not been used in reservoirs before.

ii. Positive cutoff: A cutoff wall is to be constructed as shown in Fig. 20. This procedure is very risky to be executed now on Mosul Dam. The risk involves the great height of the cutoff wall, hardness of pervious strata, presence of cavities and voids in the foundation, in addition to maintaining the verticality of the diaphragm panels at these unprecedented depths.
Table 5 Affected population for different periods and depths of inundation level in five major cities along river course (Annunziato et al. 2016)

\begin{tabular}{|c|c|c|c|c|c|c|c|}
\hline RWL & $\mathrm{T}$ & Inundation & Mosul & Bayji & Tikrit & Samara & Baghdad \\
\hline \multirow[t]{5}{*}{330} & \multirow[t]{5}{*}{6} & $0.1-0.5$ & 21,000 & 0 & 0 & 0 & 746,000 \\
\hline & & $0.5-2.0$ & 55,000 & 300 & 100 & 3000 & $2,949,000$ \\
\hline & & $2-5$ & 41,000 & 400 & 2500 & 100 & $1,134,000$ \\
\hline & & $5-10$ & 60,000 & 17,000 & 14,000 & 5500 & 26,000 \\
\hline & & $>10$ & 183,000 & 2000 & 4000 & 3500 & 0 \\
\hline \multirow[t]{5}{*}{319} & \multirow[t]{5}{*}{6} & $0.1-0.5$ & 27,000 & 0 & 0 & 0 & 803,000 \\
\hline & & $0.5-2.0$ & 12,000 & 500 & 0 & 0 & $1,756,000$ \\
\hline & & $2-5$ & 510,000 & 15,000 & 3500 & 1000 & 750,000 \\
\hline & & $5-10$ & 66,000 & 4500 & 14,000 & 10,000 & 78,000 \\
\hline & & $>10$ & 125,000 & 0 & 500 & 1000 & 0 \\
\hline \multirow[t]{5}{*}{300} & \multirow[t]{5}{*}{12} & $0.1-0.5$ & 14,000 & 500 & 500 & 1000 & 382,000 \\
\hline & & $0.5-2.0 \mathrm{~m}$ & 15,000 & 9500 & 7000 & 7000 & 850,000 \\
\hline & & $2-5$ & 86,000 & 3500 & 8000 & 3000 & 229,000 \\
\hline & & $5-10$ & 54,000 & 0 & 500 & 500 & 60,000 \\
\hline & & $>10$ & 4000 & 0 & 0 & 0 & 0 \\
\hline
\end{tabular}


iii. Construction of a new curtain: This is to be done as a direct reinforcement to the existing curtain; this assumes that it could be done in a better geological location in the upstream of the dam in order to provide improvement. The geological conditions are not different upstream the dam and the construction require the drawing down of the reservoir then such proposal had no value.

The Ministry of Irrigation asked an expert (Mr. Mariotti) to further discuss the problem of the curtain and give suggestions. His report was submitted to the International Board of Experts (IBOE, 1989) and the following proposals were given:

In the context of strengthening the grout curtain in the problem areas where massive grouting had to be repeated widening the curtain was recommended. Additional rows of boreholes ought to be drilled consisting of one row upstream of the present curtain and slightly inclined towards the upstream, another row in the downstream of the present curtain and inclined towards downstream, and finally a central vertical row in between. The central row was to be grouted first followed by the upstream row and then the downstream. Finally, the central row would be re-drilled and fine grouting to be performed using silica gel. The Board did not object to this proposal as machinery and grouting capacity were available. The second solution was to construct a tunnel the length of the chalky series from which grouting would be performed. The Board thought that such work was very specialized and would need expert studies to check its feasibility.
The third solution was to construct a series of tunnels and galleries to replace risky material. This alternative received the same comments as in (b) above.

The fourth alternative was to construct a diaphragm wall from the upstream berm, with a sloping concrete facing from the top of the diaphragm to the top of the dam (Fig. 21). Or even to remove part of the top of the dam and install the diaphragm through the core in a location upstream of the gallery. This arrangement was attributed to the unavailability of machines that could cut to the desired level. In a later update, the removal of the dam top was thought unnecessary due to new development in diaphragm machines. The Board; however, judged this solution undesirable due to the required lowering of the reservoir level, which could extend 2-3 years in addition to the very high cost.

All the discussed alternatives were not practical and some of them were even not feasible. Therefore, it was decided to continue the works on the present curtain by improving the mixes and injection procedure to combat large take areas, sealing large pipes and channels, providing a new array of piezometers taping the known solution areas especially the contact between the pervious limestone and gypsum GB0 layers to monitor the efficiency and the long term performance of the curtain in these soluble layers where windows were most likely would develop.

To take some protective measures due to the possible failure of Mosul Dam, to secure the safety of the downstream area and its' population the

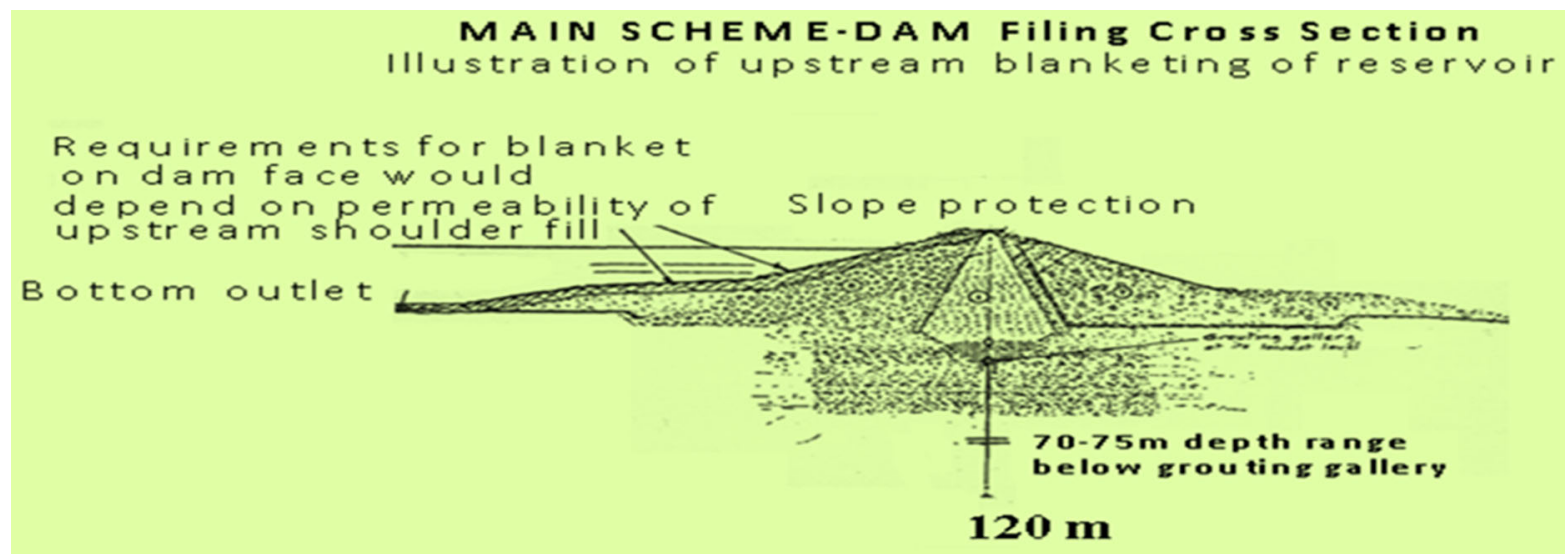

Fig. 19 Illustration of upstream blanketing arrangement 


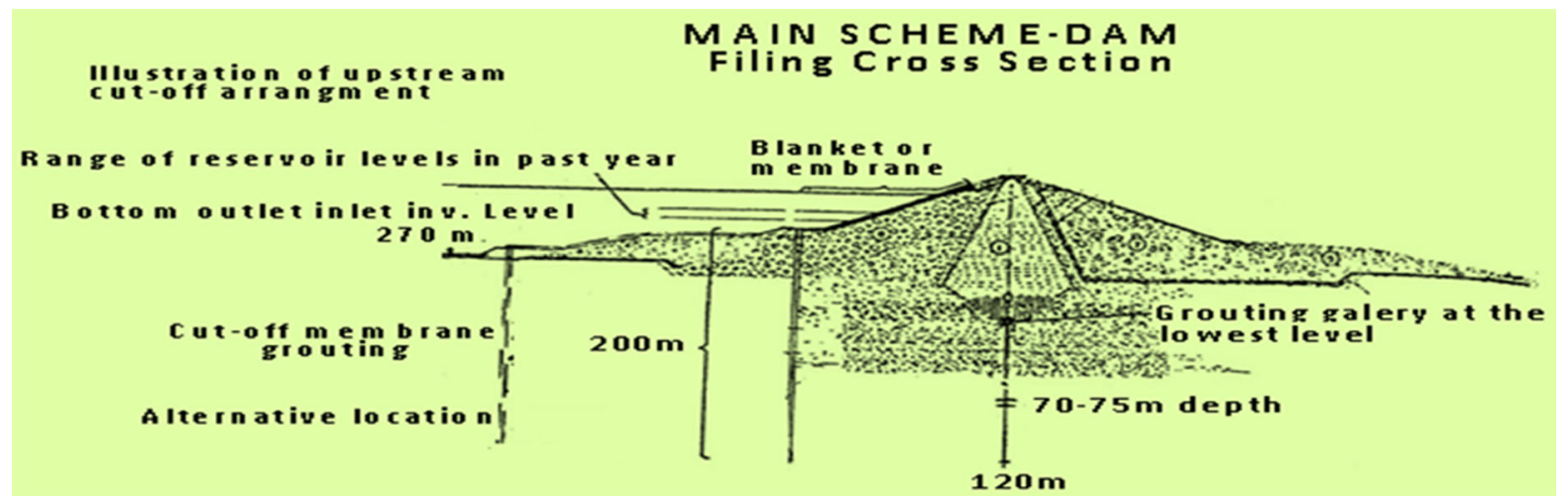

Fig. 20 Illustration of upstream cut-off arrangement

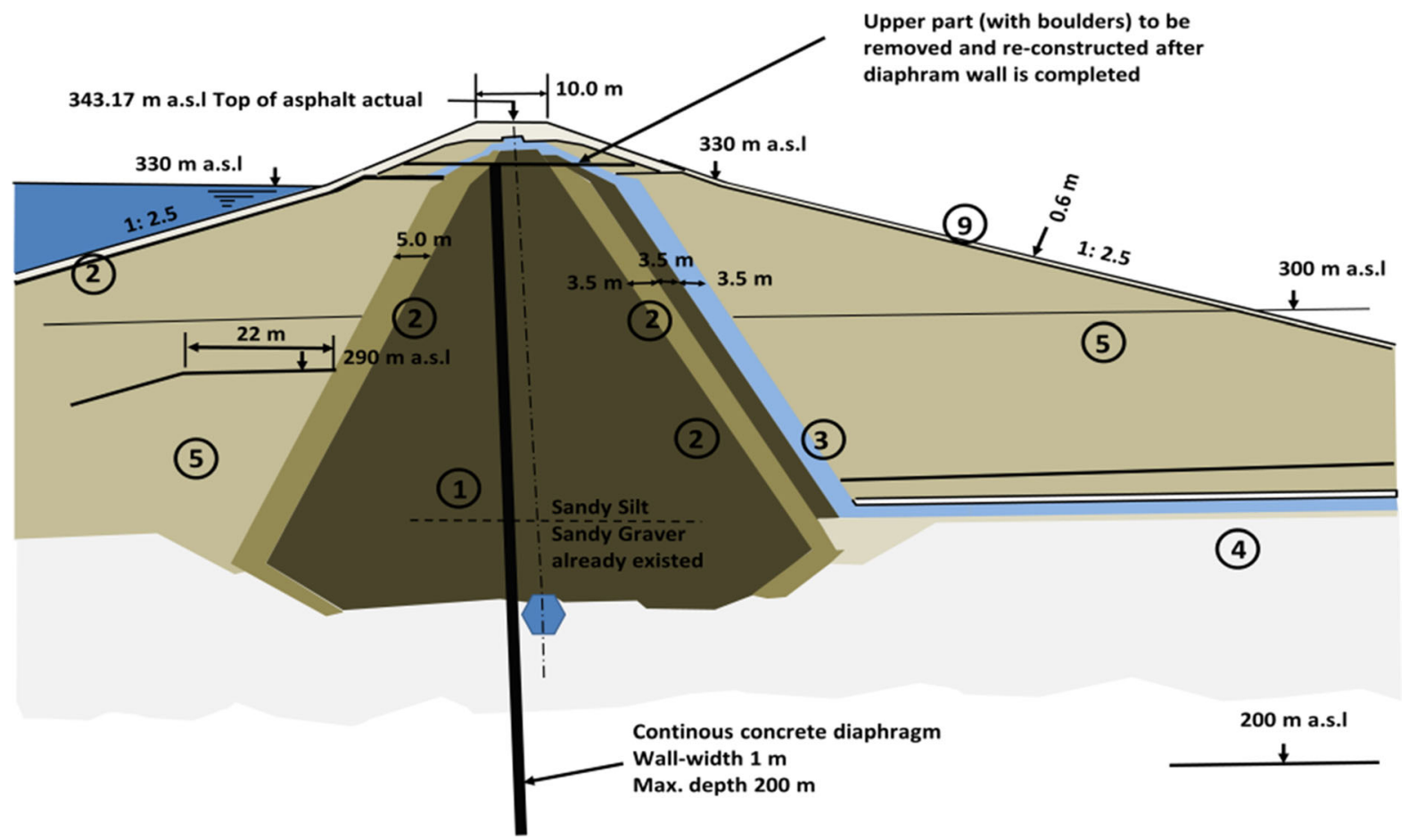

Fig. 21 Proposed Diaphragm driven from the dam crest

Ministry of Irrigation decided to construct Badush Dam in 1988. The design and construction of Badush Dam were initiated in 1988 using fast track method to complete the dam within four years. It is located on the Tigris River, approximately $40 \mathrm{~km}$ downstream from Mosul Dam site and approximately $15 \mathrm{~km}$ upstream of Mosul city (Fig. 22). Other functions of the dam were power generation using water discharged by Mosul Dam and by the regulating scheme power plants. The work on this dam was halted in 1991 due to UN sanctions on Iraq.

\section{Conclusion and Recommendations}

Mosul Dam is suffering from the seepage problem under the foundation of the dam since the start of its operation in 1986. Various works 


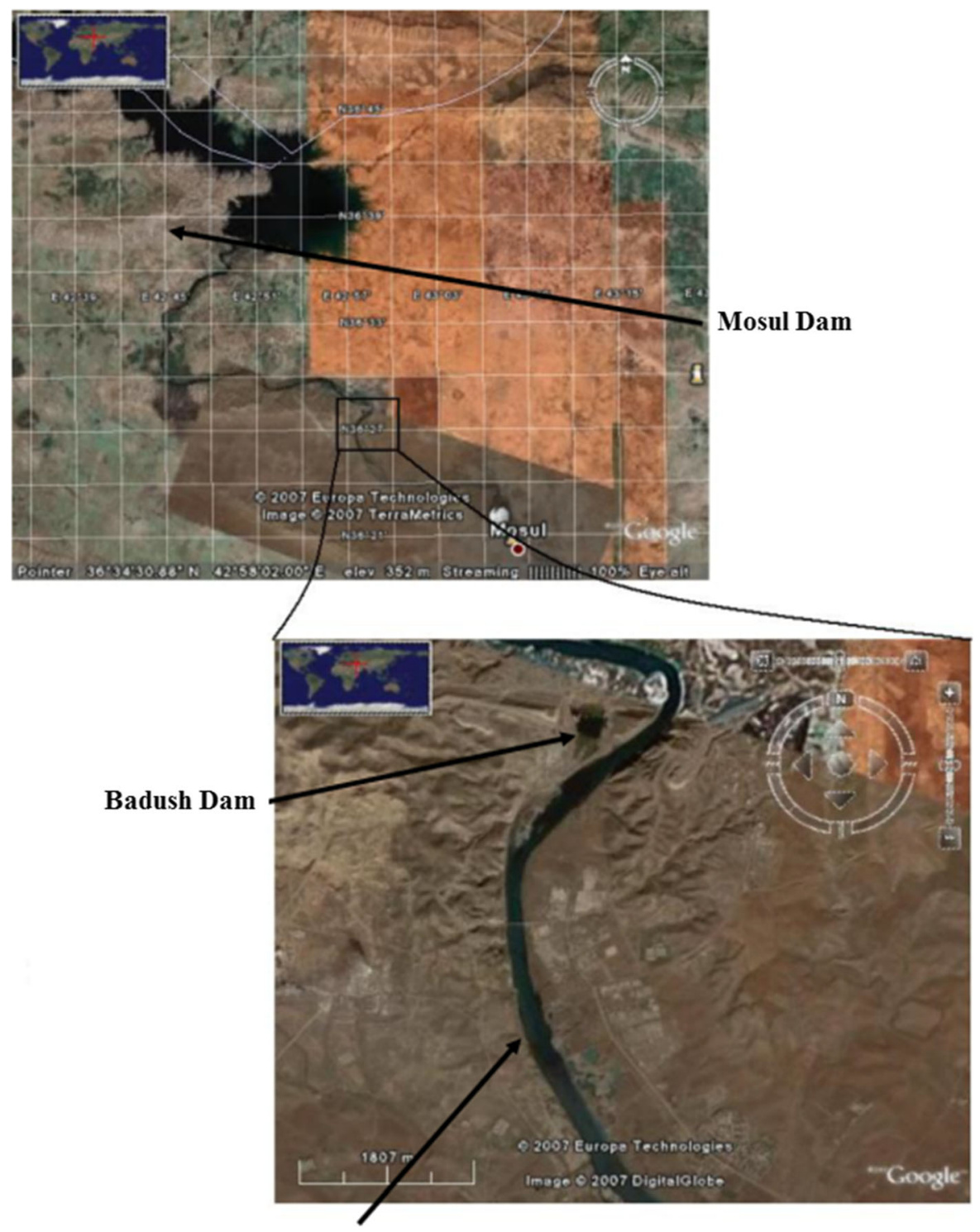

River Tigris

Fig. 22 Badush Dam location in relation to Mosul Dam (Al-Adily et al. 2014)

had been done to overcome the problem, but it seems that the dam is showing more and more signs of weakness. In view of all the published work and meetings it is well understood that the geology of the dam site is very complicated and it suffers from severe problems due to the presence of badly jointed and cavernous soluble gypsum/anhydrite layers, gypsum breccias layers, weathered and jointed limestone and soft marls. The consultants had underestimated these problems where impounding have increased the solubility of the rocks within the vicinity of the dam and enhance the formation of sinkholes. Despite all the intensive maintenance work the dissolution of gypsum continued and the gypsum breccias layers were very much resistant to grouting at the deep grout curtain zones. Furthermore, it is evident from the work done that grouting can only be a temporary solution where it cannot stop permanently the dissolution of gypsum. In addition, it is causing weakening of the rocks by the re-grouting process; it cannot 
stop the progressive formation of sinkholes and, moreover it is giving a false sense of security. Looking at the report, papers and discussions of researchers and experts, it is believed that the following points are to be considered:

- Keeping the reservoir water level as low as possible for such a period that might be necessary subject to updated risk analysis.

- It is very important to continue grouting operations and to evaluate the existing monitoring program and upgrade the system with new available instrumentation to pin point the most critical locations to be grouted.

- Providing possible early warning system for changing conditions that may indicate where and when a failure mechanism is developing.

- Bathymetric survey should be conducted to determine the points of excessive leakage from the reservoir and to detect any sinkhole, spring and seeps within the upstream area in the reservoir close to the dam.

- Emergency Action plan should be developed and implemented and the public should be aware of such a plan.

- A new panel of experts is to be established to meet every three months to review the status of the grouting program and any new development.

- Since grouting is not the final solution for the problem, other alternatives are to be carefully studied and a decision should be taken to solve this problem. These solutions may require to include the construction of a diaphragm in Mosul Dam, completion of Badush Dam or a hybrid solution of both.

Acknowledgements Open access funding provided by Lulea University of Technology.

Open Access This article is licensed under a Creative Commons Attribution 4.0 International License, which permits use, sharing, adaptation, distribution and reproduction in any medium or format, as long as you give appropriate credit to the original author(s) and the source, provide a link to the Creative Commons licence, and indicate if changes were made. The images or other third party material in this article are included in the article's Creative Commons licence, unless indicated otherwise in a credit line to the material. If material is not included in the article's Creative Commons licence and your intended use is not permitted by statutory regulation or exceeds the permitted use, you will need to obtain permission directly from the copyright holder. To view a copy of this licence, visit http://creativecommons.org/licenses/by/4.0/.

\section{References}

Adamo N, Al-Ansari NA (2016a) Mosul Dam full story: safety evaluation of Mosul Dam. J Earth Sci Geotech Eng 6(3):185-212

Adamo N, Al-Ansari NA (2016b) Mosul Dam full story: engineering problems. J Earth Sci Geotech Eng 6(3):213-244

Adamo N, Al-Ansari NA (2016c) Mosul Dam full story: what if the dam fails? J Earth Sci Geotech Eng 6(3):245-269

Adamo N, Al-Ansari NA, Issa IE, Sissakian V, Knutsson S (2015a) Mystery of Mosul Dam the most dangerous dam in the world: problems encountered during and after impounding the reservoir. J Earth Sci Geotech Eng 5(3):47-58

Adamo N, Al-Ansari NA, Issa IE, Sissakian V, Knutsson S (2015b) Mystery of Mosul Dam the most dangerous dam in the world: foundation treatment during construction. J Earth Sci Geotech Eng 5(3):59-69

Adamo N, Al-Ansari NA, Issa IE, Sissakian V, Knutsson S (2015c) Mystery of Mosul Dam the most dangerous dam in the world: maintenance grouting. J Earth Sci Geotech Eng 5(3):71-77

Adamo N, Al-Ansari NA, Issa IE, Sissakian V, Knutsson S (2015d) Mystery of Mosul Dam the most dangerous dam in the world: experts proposals and ideas on Mosul Dam. J Earth Sci Geotech Eng 5(3):79-93

Al-Abayachi S (2016) Report on Mosul Dam, Iraqi House of Representatives. Agriculture, water, and Marshes SubCommittee. https://drive.google.com/file/d/ 0Byn0PFg9wZ5FNHNQUmxLb0JzenM/view, Accessed 26 Jan 2017

Al-Adily A, Khasaf S, Ajaj A (2014) Hydrological Impacts of Iraqi Badush Dam on Ground Water. Int Water Technol J 4(2):90-106

Al-Ansari NA, Issa IE, Sissakian V, Adamo N, Knutsson S (2015a) Mystery of Mosul Dam the most dangerous dam in the world: the project. J Earth Sci Geotech Eng 5(3):15-31

Al-Ansari NA, Adamo N, Issa IE, Sissakian V, Knutsson S (2015b) Mystery of Mosul Dam the most dangerous dam in the world: karstification and sinkholes. J Earth Sci Geotech Eng 5(3):33-45

Al-Ansari NA, Adamo N, Issa IE, Sissakian V, Knutsson S (2015c) Mystery of Mosul Dam the most dangerous dam in the world: dam failure and its consequences. J Earth Sci Geotech Eng 5(3):91-111

Al-Ansari NA, Adamo N, Sissakian V, Knutsson S (2015d) Geological and Engineering investigations of the most dangerous dam in the world. SCIENPRESS, London

Al-Ansari NA, Barazanji A, Al-Jabari M, Gayara A (1984) Geological investigation of Mosul Dam Site. Report submitted to the Ministry of Irrigation, Iraq, 41p.

Al-Sinjari, M. A. (2007) Characterization and classification of some vertisols west of duhok governorate, $\mathrm{PhD}$. thesis, University of Mosul, Iraq. 
Al-Taiee TM, Rasheed MM (2009) Simulation Tigris River Flood Wave in Mosul City due to hypothetical Mosul Dam. In: Thirteenth International Water Technology Conference, IWTC 13 2009, Hurghada, Egypt

Annunziato A, Andredakis I, Probst P (2016) Impact of flood by a possible failure of the Mosul Dam, Version 2, Joint Research Centre (JRC) technical reports, EU Commission, April 2016. https://publications.jrc.ec.europa.eu/ repository/bitstream/JRC101555/lbna27923enn.pdf Accessed 26 Jan 2017

BBC (2016) US warns of Mosul dam collapse in northern Iraq, 29 February 2016. https://www.bbc.com/news/worldmiddle-east-35690616 Accessed 26 Jan 2017

Binnie and Partners (1987) Mosul Dam Foundation Cut-off. Report, Ministry of Irrigation, Baghdad, Iraq, Sept, p 1987

Black and Veatch (2004) Mosul Dam Assessment. Review of 1984 Dambreak and Floadwave Study for Mosul Dam. Mosul Dam Library, Iraq.

CNN (2016) Iraq's Mosul Dam faces 'risk of catastrophic failure,' U.S. says, 29 February 2016.https://edition.cnn.com/ 2016/02/28/middleeast/iraq-mosul-dam/ Accessed 26 Jan 2017

Cetinic F (2016) Satellite Based Information to support Health Analysis of Mosul Dam, International workshop on Mosul Dam, 24-25 May, 2016. Stockholm.

Coffman, R. (2014) Mosul Dam Could Fail if ISIS Doesn't Continue Grouting Operations, Expert Says, University of Arkansas, Fayetteville, Article ID: 621536. https://www. newswise.com/articles/mosul-dam-could-fail-if-isisdoesn-t-continue-grouting-operations-expert-says-damcollapse-would-inundate-mosul-and-baghdad Accessed 26 Jan 2017

Deere DU, Deere DW (1989) Rock quality designation (RQD) after twenty years Contract Report GL-89-1. U.S. Army Engineer Waterways Experiment Station, Vicksburg, MS

Franchello F, Krausmann E (2008) HyFlux2: a numerical model for the impact assessment of severe inundation scenario to chemical facilities and downstream environment, EUR 23354 EN-2008 https://www.google.se/url?sa=t\&rct= $\mathrm{j} \& \mathrm{q}=\& \mathrm{esrc}=\mathrm{s} \&$ source $=$ web $\& \mathrm{~cd}=2 \& \mathrm{ved}=0$ ahUKEwiMrc DK4tfRAhWC1iwKHf9MA3wQFggeMAE\&url=http\% 3A\%2F\%2Fportal.gdacs.org\%2Fabout $\% 2$ FPublications $\%$ 2FItemID\%2F205\%2FModID\%2F662\&usg= AFQjCNEG-Mtyu2tSVcrmS_-6nWjrvmfAgw\&bvm=bv. 144224172,d.bGg Accessed 26 Jan 2017

Guzina B, Saric J, Petrovic N (1991) Seepage and dissolution at Foundation of a Dam During the First Impounding of Reservoir. ICOLD meeting, Vienne

Hijab SR, Al-Jabbar MA (2006) Geophysical investigation on Mosul Dam Area, Stage One. Emergency Microgravity Survey. Iraq Geological Survey Library. Internal report.

IBOE (1989) International Board of Experts, Interim Meeting report, Ministry of Irrigation, Baghdad, Iraq, January 1989

IVO, Imatran Voima Osakeyhtio (1969) Consulting engineers, Finland, geologic map of Mosul Dam, Ministry of Agrarian Reform, Iraq

Iraq-business news, 2016, Iraq signs contract with Italian firm to consolidate Mosul Dam, 3rd March, 2016. https://www. iraq-businessnews.com/2016/03/03/iraq-signs-contractwith-italian-firm-to-consolidate-mosul-dam/ Accessed 26 Jan 2017
Iraqi Ministry of Water Resources (2012a) Water Resources, Mosul Dam. https://dams.mowr.gov.iq/node/11 Accessed 11 Dec 2016

Iraqi Ministry of Water Resources (2012b) Water resources, Mosul dam. https://dams.mowr.gov.iq/node/11 Accessed 26 Jan 2017

Issa EI, Al-Ansari NA, Knutsson S (2013) Changes in Bed Morphology of Mosul Dam Reservoir. J Adv Sci Eng Res 3(2):86-95

Kelly J, Wakeley LD, Broadfoot SW, Pearson ML, McGill TE, Jorgeson JD, Talbot CA, McGrath CJ (2007) Geologic setting of Mosul Dam and its engineering implications, final report, U.S. Army Engineer District, Gulf Region, Baghdad, Iraq.

Lane PA, Griffiths DV (2000) Assessment of stability of slopes under drawdown conditions. J Geotech Geoenviron Eng 126:443-450

Lga R (1986) Report on visit in february 1986 concerning grouting works. GEOCONSEIL, Ministry of Irrigation, Baghdad, Iraq

MaCleanathan JT (2009) Update for screening portfolio risk analysis for U.S Army Corps of Engineers Dams. Risks and Reliability Directorate, USACE.

Mahmud MI, Al Azawi AO, Abdul Majeed AT, Khalil TW (2015) Mosul Dam break scenario and its effects on the areas along the river down to Baghdad, ministry of higher education and scientific research, center for catastrophes data management and space archives, Baghdad Nov. 2015 (in Arabic)

Mark and Wheeler (2004) Mosul Dam assessment task order no. 8. Report on site visit, Mosul Dam Library, 3-7 September, 2004.

Middle East (2016) US Warning of 'Catastrophic Failure' of Iraq's Mosul Dam, 29 February 2016. https://www. voanews.com/a/us-warning-of-catastrohpic-failure-ofiraq-mosul-dam/3212415.html Accessed 26 Jan 2017

Milillo P, Bürgmann R, Lundgren P, Salzer J, Perissin D, Fielding E, Biondi F, Milillo G (2016) Space geodetic monitoring of engineered structures: the ongoing destabilization of the Mosul dam Iraq. Nat Sci Rep. https://doi.org/ 10.1038/srep37408

New Civil Engineering (2016) Trevi continues dam repairs despite Mosul battle, 20th October, 2016. https://www. newcivilengineer.com/world-view/trevi-continues-damrepairs-despite-mosul-battle/10012949.article Accessed 26 Jan 2017

Sissakian VK (1978) Report on the geological mapping of Tuz Khurmatu-Kifri-Kalar Area. Iraq Geological Survey Library report no. 902.

Sissakian VK, Al-Mousawi HA (2007) Karstification and related problems, examples from Iraq. Iraqi Bull Geol Min 3(2):1-12

Sissakian VK, Ibrahim FA (2004) Geological hazards map of mosul quadrangle, scale 1:250000. Iraq Geological Survey Library report no. 2860.

Sissakian VK, Fouad SF, Salih HA (2003) The Landslides of Khanooqa Area, Central part of Iraq. Iraqi Journal of Earth Sciences, Mosul University, Mosul, Iraq, vol 3, p 1.

Sissakian VK, Fouad SF, Al-Musawi HA (2005) The influence of the unstable slopes on the stability of Makhul Dam. Central Iraq Iraqi Bull Geol Min 2(1):31-44 
Sissakian VK, Abdul Ahad AD, Hamid AT (2011) Geological hazards in Iraq, classification and geographical distribution. Iraqi Bull Geol Min 7(1):1-28

Sissakian VK, Al-Ansari N, Knutson S (2014) Karstification problems in Mosul Dam and its assessment. North Iraq Eng 6(2):84-92

Sissakian V, Al-Ansari NA, Issa IE, Adamo N, Knutsson S (2015) Mystery of Mosul Dam the most dangerous dam in the world: general geology. J Earth Sci Geotech Eng $5(3): 1-13$

Swiss consultants (1979) Mosul Dam Project-planning report, State organization of Dams, Republic of Iraq, Ministry of Irrigation, vol 1.

Swiss Consultant (1984a) Mosul Dam project hydrological study on right bank report, state organization of dams, Republic of Iraq, Ministry of Irrigation, June 1984

Swiss Consultants (1984b) Security measures II, Addendum 3Flood wave studies, Task 2 Mosul flood wave, Confidential report for the Ministry of Irrigation, State Organization of Dams, vol 1 (Summary), vol 2 (The model and model calibration), vol 3 (Calculation of Mosul flood wave), 1984.

Swiss Consultants Consortum. (1984c) Mosul Dam flood wave, summary, vol I, Feb. 1984.

Swiss Consultants Consortum (1984d) Mosul Dam flood wave, model calibration, vol II, Feb. 1984.
Swiss Consultants Consortum (1984e) Mosul Dam flood wave, calculation, Vol III, Feb. 1984.

U.S. Department of the Interior Bureau of Reclamation (2014) Interim RCEM-reclamation consequence estimating methodology. Guidelines for estimating life loss for dam safety risk analysis, February.

Wakeley LD, Kelley JR, Talbot CA, Pearson ML, Broadfoot SW (2007) Geologic conceptual model of Mosul Dam. U.S. Army Engineer Research and Development Center, $61 \mathrm{p}$.

Washington Group International \& Black and Veatch (2005) Review of 1984 dam break and flood wave study on Mosul Dam. Iraq. Final Report-Task order No. 8. Mosul Dam, Appendix H. August 2005

Wheeler M, Ackers J, Bartlett J, Tarrant F, Dunlop C, Campbell P (2004) Mosul Dam assessment, review of 1984 dam break and flood wave study for Mosul Dam, Iraq. Black and Veatch, UK

Wheeler M, Ackers J, Bartlett J, Tarrant F, Dunlop C, Campbell P (2005) Mosul Dam study, task order 8. Blach and Vetatch, Surrey

Publisher's Note Springer Nature remains neutral with regard to jurisdictional claims in published maps and institutional affiliations. 